\title{
SALT ACCUMULATION AND EFFECTS WITHIN FOLIAGE OF TILIA X VULGARIS TREES FROM THE STREET GREENERY OF RIGA, LATVIA
}

\author{
Gunta Cekstere $^{1}$, Anita Osvalde ${ }^{2}$, Didzis Elferts ${ }^{2}$, Christophe Rose $^{3}$, Falk Lucas ${ }^{4}$, and \\ Pierre Vollenweider ${ }^{5}$ \\ ${ }^{1}$ Institute of Biology University of Latvia \\ ${ }^{2}$ University of Latvia \\ ${ }^{3}$ INRA Nancy Research Centre \\ ${ }^{4} \mathrm{ETH}$ Zurich \\ ${ }^{5}$ Swiss Federal Institute for Forest Snow and Landscape Research
}

May 5, 2020

\begin{abstract}
Green infrastructures within sprawling cities provide essential ecosystem services, increasingly undermined by environmental stress. The main objective in this study was to relate the allocation patterns of $\mathrm{NaCl}$ contaminants to injury within foliage of lime trees mechanistically and distinguish between the effects of salt and other environmental stressors. Using field material representative of salt contamination levels in the street greenery of Riga, Latvia, the contribution of salt contaminants to structural and ultrastructural injury was analyzed, combining different microscopy techniques. On severely salt-polluted and dystrophic soils, the foliage of street lime trees showed foliar concentrations of $\mathrm{Na} / \mathrm{Cl}$ up to $13600 / 16750 \mathrm{mg} \mathrm{kg}-1 \mathrm{but}$ a still balanced nutrient content. The salt contaminants were allocated to all leaf blade tissues and accumulated in priority within mesophyll vacuoles, changing the vacuolar ionic composition at the expense of especially $\mathrm{K}$ and Ca. The size of mesophyll cells and vacuoles was increased as a function of $\mathrm{NaCl}$ concentration, suggesting impeded transpiration stream. In parallel, the cytoplasm showed degenerative changes, suggesting indirect stress effects. Hence, the lime trees in Riga showed tolerance to the dystrophic environmental conditions enhanced by salt pollution but their leaf physiology appeared directly impacted by the accumulation of contaminants within foliage.
\end{abstract}

\section{ACKNOWLEDGEMENTS}

We thankfully acknowledge technical support by Terry Menard (light and electron microscopy), Dalinda Bouraoui (pedological assessments), James Whitby and Lex Pillatsch from EMPA in Thun, Switzerland (FIB-Tof-SIMS trials), Andres Kaech from ZMB, University of Zurich (cryo-fixation of samples and freeze substitution trials), Roger Wepf and Maja Günthert from ScopeM, ETH Zurich (cryo-sectioning). We are also grateful for financial support by the Sciex-NMS ${ }^{\text {ch }}$ program (grant 14.038), Wütrich and Mathey-Dupraz Fund, and the Basic Research Funding of University of Latvia for the project ZD2015/AZ81.

\section{Introduction}

During the winter season, different chemical and abrasive materials are being spread for de-icing road and sidewalk pavement, with cheap sodium chloride ( $\mathrm{NaCl}$ ) most commonly used (Dobson, 1991, Cunningham et al., 2008, Fayun et al., 2015, Ordóñez-Barona et al., 2018, Dmuchowski et al., 2019). Alone, moistened or 
mixed with sand, the amounts of $\mathrm{NaCl}$ reach 19.6 tons per lane $\mathrm{km}$ in New York State (1.1 million tons year ${ }^{-1}$, Cunningham et al., 2008), more than 200'000 tons in Poland (Marosz, 2011), 16'000-31'500 tons in Edmonton (Equiza et al., 2017), $2 \mathrm{~kg} \mathrm{~m}^{-2}$ in Denmark (Pedersen et al., 2000) and $4.06 \mathrm{~kg} \mathrm{~m}^{-2}$ in Riga (Cekstere et al., 2008) annually. Such high amounts cause substantial environmental contamination by leaching and uptake in the surrounding soil and vegetation during the subsequent vegetation seasons (Pedersen et al., 2000, Bryson \& Barker 2002; Ordóñez-Barona et al., 2018, Nikolaeva et al., 2019). The contaminants absorbed by roots and translocated to foliage cause leaf necrosis, crown defoliation, twig dieback and street tree decay (Dobson, 1991, Bryson \& Barker, 2002, Paludan-Müller et al., 2002, Cekstere et al., 2008, Dmuchowski et al., 2014, Milewska-Hendel et al., 2017). In turn, the important ecosystem services provided by street trees, such as cooling of urban climate, mitigation of air pollution, reduction of street runoff or promotion of biodiversity can be seriously affected (Moser et al., 2015, Nowak et al., 2017; Bouraoui et al., 2019).

In street greeneries, $\mathrm{NaCl}$ contamination affects the whole urban ecosystem. In the soil compartment, $\mathrm{Na}$ accumulation destroys the soil aggregates, thus reducing the soil porosity and promoting puddling in the case of fine-textured soils (Marschner \& Marschner, 2012; Bryson \& Barker, 2002). The effects on soil chemistry include the degradation of soil organic matter, increase in $\mathrm{pH}$, dislodging of cations within absorption complexes or nitrate leaching as a consequence of enhanced nitrification rates (Cunningham et al., 2008; Dmuchowski et al. 2014; Eimers et al., 2015). Directly or indirectly, the soil salinization can depress the biological processes and alter the microbial communities in the rhizosphere (Ke et al., 2013). Tree lines planted on salt-contaminated soils can suffer under osmotic and ionic stress (Munns \& Tester, 2008), similar to 'physiological drought stress' (Dobson, 1991), which can reduce the leaf gas exchanges and growth rates (James et al., 2006, Munns \& Tester, 2008, Cekstere et al., 2015). Within leaf tissues, the accumulation of salt ions can impair several enzymatic activities, inhibit membrane functions, promote nutrient imbalance, decrease chlorophyll concentration, and significantly affect essential physiological activities (Muszynska et al., 2014; Negrão et al., 2017). Molecular responses and tolerance mechanisms have been extensively investigated and reviewed (Munns \& Tester, 2008; Polle \& Chen, 2015; Flowers et al., 2015; Munns et al., 2016; Wu et al., 2018). Structurally, various studies, so far not yet comprehensively reviewed, have reported about cellular responses such as enhanced oxidative stress (Hernandez et al., 1995; Benzarti et al., 2012) and numerous alterations in cytoplasm and e.g.chloroplast or mitochondria (Naidoo et al., 2011; Yamane et al., 2012; Ivanova et al., 2016;). However, quantitative evidence relating the levels of $\mathrm{NaCl}$ contamination to structural injury is still largely missing and the mechanisms of $\mathrm{NaCl}$ toxicity in foliage thus remain partly elusive (Munns \& Tester, 2008). Moreover, most reports illustrating microscopic injury miss microlocalisation evidence, complicating the distinction between direct and indirect effects by salt contaminants.

Adaptations to elevated salinity show similarities with those in the case of infertile soils (Chapin, 1980). They may have evolved in the framework of exclusion or inclusion strategies, the latter conferring lower tolerance to chronic salt stress (Chen et al., 2018). Tolerance mechanisms in includers may encompass vacuolar allocation of contaminants whilst keeping a high $\mathrm{K}^{+} / \mathrm{Na}^{+}$ratio, allocation to non-photosynthetic tissues, leaf succulence or translocation to older foliage organs (Ottow et al., 2005; Flowers et al., 2015; Polle \& Chen, 2015; Wu et al., 2018). Safe allocation of salt contaminants is thus crucially important with a view to salt tolerance in salt includers (Polle \& Chen, 2015; Munns et al., 2016). Given their high mobility however, the microlocalisation of $\mathrm{Na}^{+}$and $\mathrm{Cl}^{-}$ions within tissues and cells is demanding methodologically (Frey \& Zierold, 2003; Wu \& Becker, 2012) and still limited evidence is so far available. The latter has been obtained applying various microscopical techniques, but control evidence for excluding dislodging artefacts is generally missing.

After characterizing the extent of soil pollution by salt contaminants (Cekstere \& Osvalde, 2013) or the toxic impact of high salt concentration in foliage (Cekstere et al., 2008), the present study has focused on mechanistic aspects of chronic salt stress in foliage of urban lime trees (Tilia spp. ) in the street greenery of Riga, Latvia. Its main objectives included to 1) relate the allocation of salt contaminants within leaf tissues and cell compartments to injury at cell, tissue and whole leaf level, 2) identify the most characteristic symptoms and cellular responses to salt stress and 3) distinguish direct and indirect salt stress effects from those by other environmental factors. We had the following working hypotheses: 1) by changing the nutrient balance in the soil, the de-icing salt contaminants cause nutrient imbalance within foliage of street trees; 2) 
the salt contaminants are primarily allocated to safe storage compartments, including the epidermis at leaf (2a) and vacuole at cell (2b) level; 3 ) salt accumulation in leaves causes specific structural changes relating to storage (3a) and toxicity (3b). Using 8 street sites forming a gradient of foliage contamination representative of the salt pollution in Riga's street greenery (Cekstere et al., 2008), we 1) characterized the soil and foliage chemistry, 2) analyzed the distribution of salt contaminants and main nutrients within foliar tissues and cells and 3) quantified structural and ultrastructural markers of salt stress within assimilating tissues.

\section{Material and methods}

\section{Study sites and sampling}

Riga, Latvia (Fig. 1) is located within the boreo-nemoral climate zone $\left(56.9489^{\circ} \mathrm{N}, 24.1064^{\circ} \mathrm{E}\right)$ and its green infrastructures amounts to $8 \%$ of downtown percentage area (Nikodemus et al., 2003). During winter, most precipitations $(126 \mathrm{~mm})$ fall in the form of snow and, given the 90 days per year with freezing temperatures, mostly cheap $\mathrm{NaCl}$ salts are extensively used for deicing the street pavement (Table 1). Soils in Riga's downtown have evolved from Baltic Ice Lake sandy deposits and show a primarily sandy texture ( $>85 \%$ sand, $1-12 \%$ silt, $<5 \%$ clay). Those supporting street lines of trees are weakly structured, compacted, highly heterogeneous with low to medium proportions of anthropogenic artefacts and they show a low biological activity with a maximum of $6.5 \%$ organic matter in the topsoil (Bouraoui et al., 2019), overall typical for anthroposoils (IUSS Working Group WRB, 2014). In addition, salt sludge splashing and salt-contaminated snow heap melting at the foot of trees cause salt pollution more than 20 times higher than away from pavement, especially by the end of winter (Cekstere et al., 2008, Cekstere \& Osvalde, 2013). Given the high heterogeneity of latter contamination in the soils of Riga's downtown, even within the same street section, peak $\mathrm{Na} / \mathrm{Cl}$ concentrations in March can thus range between 132-1568/26-745 $\mathrm{mg} \mathrm{kg}^{-1}$, decreasing then during the vegetation season and away from pavement. Air pollution forms another environmental issue in Riga's downtown, with still increasing levels of $\mathrm{NO}_{2} / \mathrm{NO} / \mathrm{O}_{3} / \mathrm{CO} / \mathrm{PM} 10$ (Anonymous, 2014).

For studying salt pollution and its effects in Riga's street greenery, seven street sites with salt contamination levels in foliage representative of the full range of $\mathrm{Na}$ and $\mathrm{Cl}$ concentrations measured at downtown roadside sites were selected (Cekstere \& Osvalde, 2013). Two sites showed slight (about $900 \mathrm{mg} \mathrm{kg}^{-1}$ ), two others medium (about $4500 \mathrm{mg} \mathrm{kg}^{-1}$ ) and the last three severe (about $9000 \mathrm{mg} \mathrm{kg}^{-1}$ ) salt contamination (Fig. 1). Additionally, an eighth site in a National Botanical Garden (NBG) $20 \mathrm{~km}$ southeast of Riga was added to the sampling list (uncontaminated site). The selected street sites were planted with 5 to 20 Tilia $x$ vulgaris trees, $9.4+0.2 \mathrm{~m}$ high (range: $8.1-11.2 \mathrm{~m}$ ) and around 100-year-old (approximate age range: 90-110; NBG site: $18.7+0.4 \mathrm{~m}$ high trees, range: $18.0-19.1 \mathrm{~m}$, older than 110 years). At each site, three trees with similar crown condition were randomly selected. By the end of vegetation season, soil and foliage material were collected with a view to characterize the 1) nutrient and salt contamination spectrum, 2) foliar allocation of salt contaminants and 3) structural responses in foliage.

For the analysis of soil chemistry, three 0.3 L soil cores were extracted on September 122014 from the topsoil $(0-35 \mathrm{~cm})$ at $0.5-1.5 \mathrm{~m}$ distance from the stem of each selected roadside and NBG tree and thoroughly mixed prior to transfer to the laboratory. For the chemical and structural assessments in foliage, one unshaded branch per street or NBG tree, about $50 \mathrm{~cm}$ long, with around 60-70 leaves and located at 3-5 m high in the lower part of crown canopy, was pole-pruned on September 16, 2014. The average percentage area of necrosis per leaf was estimated visually in the field and the scores attributed to one out of 6 leaf injury classes (asymptomatic: 0\%, starting injury: 1-5\%, moderate injury: 6-15\%, intermediate injury: 16-30\%, severe injury; $31-50 \%$, very severe injury: $51-100 \%$ ). About 50 leaves were gathered for chemical analysis whereas disks $10 \mathrm{~mm}$ in diameter were excised from green tissues next to the leaf rim and apart main central vein in the $2^{\text {nd }}$ or $3^{\text {rd }}$ leaf from branch apex, with a view to microscopy assessments and given the location of salt injury (Fig. 2). These samples were immediately fixed using $2.5 \%$ EM- or LM-grade glutaraldehyde, buffered at $\mathrm{pH} 7.0$ with $0.067 \mathrm{M}$ Soerensen phosphate buffer. Back to the laboratory, they were fully evacuated prior to storage in renewed fixing solution at $4{ }^{\circ} \mathrm{C}$, waiting for further processing. 
With a view to the microlocalisation of salt contaminants within leaf tissues and cells, the remaining branch material was stored in a cooler and transferred on the same day to the Centre for Microscopy and Image Analysis (ZMB) of the University of Zurich, Switzerland. On the following two days, $2 \mathrm{~mm}$ disk samples excised at the aforementioned leaf center and rim location (Fig. 2) were fixed by means of high-pressure freezing (HPF) in liquid nitrogen (LN2) using a LEICA EM HPM 100 (Leica Microsystems), after 10 min evacuation in 1-Hexadecene $92 \%$ and insertion in $3 \mathrm{~mm} \mathrm{Al}$ sample carrier $(0.2 \mathrm{~mm}$ recess). The fixed leaf samples were stored in LN2 until further processing.

\section{Assessment of nutrients and salt contaminants in the soil and foliage}

The concentration of nutrients and contaminants in the harvested soil and foliage samples was measured at the Laboratory of Plant Mineral Nutrition in Latvia. In the case of soil samples and for a majority of elements (N, P, K, Ca, Mg, S, Fe, Mn, Zn, Cu, Mo, B, Na), the air-dried and $2 \mathrm{~mm}$-sieved soil samples were extracted using 1:5 (v/v) soil:1 M HCl extracting mixtures for 1 hour (Osvalde, 2011). P, S and Mo were separated from other elements by oxidizing $100 \mathrm{ml}$ extracts with hot conc. $\mathrm{HNO}_{3}, \mathrm{H}_{2} \mathrm{O}_{2}$ and $\mathrm{HClO}_{4}$ and dissolving the retrieved salts in diluted $\mathrm{HCl}$ (Rinkis et al., 1987). The concentration of $\mathrm{Ca}, \mathrm{Mg}, \mathrm{Fe}, \mathrm{Cu} \mathrm{Zn}$ and $\mathrm{Mn}$ was determined by means of atomic absorption spectroscopy, using an acetylene-air flame atomizer (Perkin Elmer Aanalyst 700; Rinkis et al., 1987; Motsara \& Roy, 2008). That of P, Mo, N, and B was estimated by colorimetry, using molybdenum blue in acid-reduced medium $(\mathrm{P})$, thiocyanate in acid-reduced medium (Mo), Nessler's reagent in alkaline medium after modified Kjeldal digestion (N), hinalizarine in sulfuric acid medium (B), whereas $\mathrm{S}$ was measured by turbidimetry after adding $\mathrm{BaCl}_{2}$, using a JENWAY 6300 spectrophotometer (Barloworld Scientific Ltd., Gransmore Green Felstad, Dunmow, Essex, UK). The concentration of $\mathrm{K}$ and $\mathrm{Na}$ was measured by flame photometry using a JENWAY PFPJ photometer (Jenway Ltd, Gransmore Green, Felsted Dunmow, Essex, UK). Estimates of $\mathrm{Cl}$ were obtained by $\mathrm{AgNO}_{3}$ titration after distilled water extraction All analyses were performed in triplicates.

For estimates of mineral nutrients and contaminants in the foliage of lime trees, the harvested leaf samples were washed in distilled water, dried 24 hours at $+60{ }^{\circ} \mathrm{C}$, and ground to powder using a laboratory mill (IKA, A11 basic, Germany). Nutrients and contaminants were extracted by dry-ashing the milled samples using concentrated $\mathrm{HNO}_{3}$ vapors and dissolving the mineral fraction in either $3 \% \mathrm{HCl}(\mathrm{P}, \mathrm{K}, \mathrm{Ca}, \mathrm{Mg}, \mathrm{Fe}$, $\mathrm{Mn}, \mathrm{Zn}, \mathrm{Cu}, \mathrm{Mo}, \mathrm{B}, \mathrm{Na}$ ) or distilled water $(\mathrm{Cl})$. In the case of $\mathrm{N}$ and $\mathrm{S}$, the milled samples were wet-digested in either conc. $\mathrm{H}_{2} \mathrm{SO}_{4}\left(\mathrm{~N}\right.$; modified Kjeldahl method) or conc. $\mathrm{HNO}_{3}$ and $\mathrm{HClO}_{4}(\mathrm{~S})$. All elements were analyzed using the same procedures as in the case of soil samples.

\section{Allocation of salt contaminants to leaf tissues}

The high mobility of salt ions within plant tissues (Mengel \& Kirkby, 2001; White \& Broadley, 2001; Li et al., 2017) and lack of fresh material (Rokebul Anower et al., 2017) formed challenging constraints with regard to salt microlocalisation free of dislodging artefacts. Using a freeze substitution procedure (Wu \& Becker, 2012) and with visualization and mapping of $23 \mathrm{Na}^{+}$and $35 \mathrm{Cl}^{-}$ions using a Focused Ion Beam-Secondary Ion Mass Spectrometer (FIB-SIMS) microscope, dislodging of $\mathrm{Na}$ and $\mathrm{Cl}$ contaminants from the vacuole to cytosol and cell wall compartments was observed (Fig. S1A, B versus 4I, J). As a consequence, we sectioned the deeply frozen sample-carrier sandwiches directly, focusing on the leaf rim samples and using a Leica EM FC6 ultra-cryo-microtome at ScopeM, $-150{ }^{\circ} \mathrm{C}$ cooling and LN2 flushing. Given the unrecoverable sections and distortion artefacts of stepwise freeze-dried block sample (Fig. S1C, D versus 6A-C), full cryo-conditions were also required with a view to visualizing and mapping the salt contaminants and leaf nutrients. Therefore and prior to observation, the planed samples transferred in LN2 to the UMR Silva-Silvatech Microscopy platform in Champenoux, France, were coated with $1.5 \mathrm{~nm} \mathrm{Pt}\left(-120{ }^{\circ} \mathrm{C}, 2.5 \mathrm{E}-2 \mathrm{mbar}\right.$ Ar plasma $)$ and the ice contamination freeze-etched $\left(30 \mathrm{~min},-85^{\circ} \mathrm{C}, 2.7 \mathrm{E}-6 \mathrm{mbar}\right)$, using an EM VCT100 vacuum cryo shutter (LEICA, UK) and an EM ACE600 double sputter coater. The samples were then transferred to a cryoFocused Electron Gun Scanning Electron Microscope (cryo-FEGSEM; SIGMA HD VP, ZEISS, Germany) equipped with a High Definition Back Scattered Electron Detector (HDBSD) and an Energy Dispersive Spectrometer $\left(\mathrm{X}-\mathrm{Max}^{\mathrm{N}}\right.$ EDS - SDD $80 \mathrm{~mm}^{2}$; Oxford-Instruments, UK) interfaced to the SEM by the INCA software (Oxford-Instruments, UK). Element maps and line scans of salt contaminants and nutrients were 
obtained at $-160{ }^{\circ} \mathrm{C}$, using magnifications of 1.35 or $4.5 \mathrm{kX}$ and $20 \mathrm{keV}$ acceleration voltages $\left(30-35^{\circ}\right.$ take off angle, $9 \mathrm{~mm}$ work distance, $200 \mu \mathrm{s}$ dwell time, 30 frames and $1500 \mathrm{~s}$ measurement time). The smooth and homogeneous material structure of samples allowed us the quantification of contaminants and main nutrients within the vacuolar compartment. At two randomly selected leaf blade transects per sample, point measurements were performed within the vacuole of one cell per tissue (10 kV HT, 30 s measurement time). The range of electron penetration in such conditions can be estimated to 2-3 $\mu \mathrm{m}$ (Huang \& van Steveninck, 1989). The spectrometer was calibrated with reference to calcium standardization before micro-analysis. The half quantitative nutrient mass percent composition (weight \%) of vacuolar sap was estimated on the basis of deconvoluted spectra for each element (INCA-XPP matrix deconvolution). The estimates per tissue type in the two investigated leaf blade transects were averaged.

\section{Structural changes at tissue and cell level in foliage}

Structural changes within foliar tissues and cells were investigated by means of widefield light (LM) and transmitted electron microscopy (TEM) at WSL and ZMB in Switzerland. For LM, the leaf material was dehydrated with 2-methoxyethanol (3 changes), ethanol, $n$-propanol, $n$-butanol (Feder and O'Brien 1968) and embedded in Technovit 7100 (Kulzer HistoTechnik). Semi thin sections (1.5 $\mu \mathrm{m}$ thick) were cut using a Reichert UltraCut S ultramicrotome, stained in $1 \%$ acid fuchsine and $0.05 \%$ toluidine blue in acetate buffer $\mathrm{pH} 4.4$ (Feder and O'Brien, 1968) and mounted in DPX. The sections were observed using the 5x100x objectives of a Leica microscope Leitz DMRB and photographed using the INFINITY 2-1R camera and Lumenera Infinity Analyze (release 6.4) software (Lumenera Corp., Ottawa, Canada). Based on the differential diagnosis of salt versus other types of biotic and abiotic injury (Fink 1999; Günthardt-Goerg et al., 2007), salt accumulation markers (cell size and form) were measured in palisade parenchyma.

For TEM, the leaf samples were post-fixed in buffered $2 \% \mathrm{OsO}_{4}$, dehydrated by a series of graded ethanol, infiltrated by a series of graded propylene oxide/Epon 812 mixture (with DDSA, NMA and DMP hardener) and embedded in Epon. Ultra-thin sections $(70 \mathrm{~nm}$ ) were cut using the aforementioned ultramicrotome, mounted on copper grids and stained using saturated uranyl acetate in $50 \%$ ethanol and lead citrate (Reynolds procedure). Sections were observed using a Philips CM12 transmission electron microscope (TEM) and micrographs taken using the Gatan Microscopy Suite Software (Gatan Inc., Pleasanton, USA). Selecting a subsample of 5 sites spanning over the whole contamination range, changes in the frequency, size and shape of cellular structures responsive to salt accumulation were quantified by stereology (Toth, 1982; Kubínová, 1994), using medially-sectioned palisade cells, a $0.5 \mu \mathrm{m}$ grid size and the ImageJ software (https://imagej.nih.gov/ij/).

\section{Statistical analysis}

Differences between site averages of macro- and micronutrient concentrations in the foliage and soil samples from 8 sampled sites were tested by means of one-way ANOVA - checking data and residuals distribution normality and homogeneity of variance - followed by Tukey (HSD) post-hoc tests, using the Statistica 7.0 software (Statsoft Inc., Tulsa Ok). After standardization of $\mathrm{Na}$ and $\mathrm{Cl}$ data, the causal role of $\mathrm{NaCl}$ accumulation in foliage regarding the univariate changes in leaf nutrients and structural parameters was tested by means of linear mixed effects model (LMEM), using the lme4 package (Bates et al. 2015) of R software, version 3.4.2 (R Core Team 2017). The individual tree formed the statistical unit whilst the site effect was treated as a random factor. Given their correlation, separate models for $\mathrm{Na}$ and $\mathrm{Cl}$ factors were calculated. For each model, the marginal $\mathrm{R}^{2}$ was calculated using the r2glmm package (Jaeger, 2017) of $\mathrm{R}$. The correlations between structural changes, salt concentration in foliage and leaf injury were investigated by means of Pearson's correlations, also using the aforementioned Statistica software, after variable normalization. Finally, the multivariate responses of palisade parenchyma cells to salt contamination in foliage was tested by means of redundancy analysis (RDA), using the vegan package (Oksanen, et al., 2017) of R and main structural size and shape variables. The dependent matrix included structural data from the aforementioned five sites subsample used for quantitative TEM, the explanatory variables consisted of foliage concentration of salt contaminants $(\mathrm{Na}, \mathrm{Cl})$, whilst leaf injury and the study site centroids were passively projected in the hyperspace determined by the RDA axes. 


\section{RESULTS}

\section{Salt contamination and mineral nutrition in the soil rooting zone and tree foliage}

In 2014 by the end of vegetation season, the root zone soil in Riga's street lines showed sizable but very variable salt contamination. In comparison to the unpolluted NBG site (Na: $13.30 \pm 0.30, \mathrm{mg} \mathrm{kg}^{-1}$, range 12.75-13.75; Cl: $6.48 \pm 0.36 \mathrm{mg} \mathrm{kg}^{-1}$, range $6.12-7.21$ ), the highest $\mathrm{NaCl}$ concentrations in the soil were observed at sites with slight foliage contamination (Na: $373.08 \pm 158.28, \mathrm{mg} \mathrm{kg}^{-1}$, range 27.81-940.80; Cl: $43.4 \pm 16.31 \mathrm{mg} \mathrm{kg}^{-1}$, range 11.62-115.20). With 28.69/6.69 times more $\mathrm{Na} / \mathrm{Cl}$ on average than at $\mathrm{NBG}$, soil pollution thus exceeded that found in the case of severe foliage contamination, with soil concentrations of $\mathrm{Na} / \mathrm{Cl}$ then only $13.45 / 2.49$ times higher than at $\mathrm{NGB}$ (Na: $178.87 \pm 73.20, \mathrm{mg} \mathrm{kg}^{-1}$, range $34.86-$ 712.50; Cl: $16.16 \pm 3.16 \mathrm{mg} \mathrm{kg}^{-1}$, range 9.20-39.90). Similarly, the sites with intermediate versus slight foliage contamination also showed lower $\mathrm{Na} / \mathrm{Cl}$ soil pollution ( $\mathrm{Na}$ : $60.39 \pm 10.51$, mg kg-1, range 28.0689.04; $\mathrm{Cl}: 20.78 \pm 1.73 \mathrm{mg} \mathrm{kg}-1$, range 15.84-26.88) and exceedance of contamination threshold (4.54/3.21 times). At the end of summer, there was thus little agreement between the trends for $\mathrm{NaCl}$ soil and foliage contamination. Irrespective of the $\mathrm{NaCl}$ soil pollution, the nutrient supply for street trees was dystrophic because of imbalances in several mineral elements. All sites (including NBG) showed low levels of N, with regard to the sufficiency range in the case of deciduous trees (Table 2). The soil concentration of $\mathrm{K}$, $\mathrm{S}$ and $\mathrm{B}$ also showed frequent suboptimal levels. In contrast, that of other elements sometimes exceeded the tree requirements. This was especially the case of $\mathrm{Ca}$ and $\mathrm{Mg}$, which led to high soil $\mathrm{pH}$ at sites showing the largest exceedances (Valdemara, Barona, Gertrudes and Aspazijas). Elevated metal concentrations (Fe, Zn, $\mathrm{Cu}$ ) appeared in priority related to the urban location of study sites.

The sub-optimal site conditions were only partly reflected by the foliar chemistry. Compared to foliage from the unpolluted NBG site (Na: $86.00 \pm 7.57, \mathrm{mg} \mathrm{kg}^{-1}$, range $72-98 ; \mathrm{Cl}: 760.00 \pm 120.97 \mathrm{mg} \mathrm{kg}^{-1}$, range $530-$ 940 ), the average foliar concentration of salts in 2014 gradually increased from the slightly (Na: $895.00 \pm$ 476.89, $\mathrm{mg} \mathrm{kg}^{-1}$, range 118-3100; Cl: $4743.33 \pm 643.31 \mathrm{mg} \mathrm{kg}^{-1}$, range 3000-7570) to moderately (Na: 4506.67 $\pm 534.41, \mathrm{mg} \mathrm{kg}^{-1}$, range 2660-6600; Cl: $8655.00 \pm 1168.30 \mathrm{mg} \mathrm{kg}^{-1}$, range 5000-11500) and severely polluted (Na: $8000.00 \pm 793.03, \mathrm{mg} \mathrm{kg}^{-1}$, range 660-13600; Cl: 92.65.56 $\pm 1340.18 \mathrm{mg} \mathrm{kg}^{-1}$, range 3000-16750; Fig. 1) sites along the selected gradient of foliage contamination. Versus levels at $\mathrm{NBG}$, the $\mathrm{Na} / \mathrm{Cl}$ concentrations were thus $10.41 / 6.24,52.40 / 11.39$ and 93.02/12.19 times higher respectively. However, the foliage versus root zone soil of studied trees showed less nutrient imbalances on average, noteworthy with regard to $\mathrm{N}$, $\mathrm{S}$ and $\mathrm{B}$ (soil concentration below the sufficiency range) or $\mathrm{Ca}, \mathrm{Mg}, \mathrm{Zn}$ or $\mathrm{Cu}$ (soil concentrations showing exceedances; Table 3 versus Table 2). Some elements locally in excess in the root zone soil (Mn) showed, nevertheless, frequent deficiencies in the foliage, particularly at sites with high soil $\mathrm{pH}$. In the case of $\mathrm{K}$ and similar to observations in the root zone soil, the deficiencies in foliage were frequent, especially at the salt-contaminated sites. In a direct or indirect way, the elevated salt levels in foliage played a driving role regarding the observed foliar concentrations of several nutrients (Table S1A). The foliar concentration of Ca thus dropped in response to higher accumulation of $\mathrm{Na}$ and $\mathrm{Cl}$ in foliage, whilst that of $\mathrm{K}$, Mo increased with higher $\mathrm{Cl}$ - but not $\mathrm{Na}$ - contamination (Fig. 3, Table S1A). Foliar salt accumulation also led to increased Zn levels, whereas the relationship may be rather correlative than causal.

\section{Allocation of salt contaminants to tissue and cell storage compartments in foliage}

Within the 1-2 mm-long leaf rim samples visualized in cryo-microscopy and whatever the sampling site, at least $\mathrm{Cl}(\mathrm{NBG})$ or both salt ions (Riga's sites) showed a homogeneous distribution in all leaf blade tissues (Fig. 4A-C). At leaf level, the allocation was similar to that of $\mathrm{K}$ but showed differences with that of e.g. Ca (Ca-oxalate crystals and preferential epidermis location) or Si (cell wall location; results not shown). The increase in $\mathrm{Na}$ and $\mathrm{Cl}$ count frequency with higher foliar contamination of salts formed the main inter-site difference observed during the microanalytical assessments (Fig. 4D-F). At cell level (Fig. 4G-K), Na and Cl were found within vacuolar compartments, thus closely matching the allocation of K (Fig. 4I-J vs. K). Salt accumulation caused a change in the ionic composition of cell vacuoles from all leaf blade tissues within leaf rim segments (Fig. 5). In mesophyll, the Na/Cl mass fraction at salt contaminated sites reached 3.98/7.29\% (palisade parenchyma) and 3.72/8.04\% (spongy parenchyma), thus 4.63 and 12.28 times higher in the case of 
$\mathrm{Cl}$ than at the NBG site (NBG Na concentrations below the detection limit). In epidermis (E), it amounted to $3.98 / 4.30 \%$ (upper E) and 3.60/4.97\% (lower E), thus 1.21 and 8.42 times more in the case of $\mathrm{Cl}$ than at NBG. The mesophyll in leaf rim samples thus showed higher $\mathrm{NaCl}$ accumulation than epidermis. In parallel with the accumulation of salt, the vacuolar compartments within all tissues showed a marked decrease of nutrients mass fractions (Fig. 5). Especially that of $\mathrm{K}$ in mesophyll and $\mathrm{Ca}>\mathrm{K}$ in lower epidermis were lowered.

\section{Structural responses to salt accumulation in foliage}

As indicated by significant correlation with both $\mathrm{Na}(P<0.001, \mathrm{r}=0.79)$ and $\mathrm{Cl}(P=0.0007, \mathrm{r}=0.67)$, the leaves of lime trees from Riga's street greeneries showed a higher percentage area in the form of necrotic leaf rims (Fig. 2) with increasing salt accumulation. However, the LMEM models were not significant (Table S1B). In parts of leaves still asymptomatic, structural changes clearly distinct from those by biotic injury noteworthy aphids (Bouraoui et al., 2019) - were observed in the leaf mesophyll (Fig. 6) and epidermis (Fig. S2). The most striking symptom of salt accumulation was an increase in the percentage area of vacuome (Fig. 6D-F), with one large vacuole filling most of cell volume in samples with highest contamination (Fig. $6 \mathrm{I}, \mathrm{J})$. Given the ontological progress in epidermis by the time of sampling and random sectioning of spongy parenchyma cells, this marker was primarily visible in palisade parenchyma. Other palisade cell structures were increasingly condensed and degenerated (Fig. 6G-J, L, M). At subcellular level, the vacuoles showed intense autophagic activity and contained many inclusions as well as multivesicular bodies (Fig. 6I, J, L, M). Large plastoglobules, protruding towards and being extruded into the vacuole (Fig. 6L, M), had developed inside of chloroplasts. In the epidermis, mostly degenerative changes including the a) higher condensation of nuclear material (Fig. S2B, E), b) increase in size and frequency of plastoglobules within leucoplasts (Fig. $\mathrm{S} 2 \mathrm{~F}, \mathrm{G}$ ) or c) larger autophagic activity and frequency of multivesicular bodies were observed.

The LMEM models in combination with salt microlocalisation data confirmed the direct or indirect implication of subcellular accumulations of $\mathrm{Na} / \mathrm{Cl}$, with respect to the observed structural changes. The increase in the vacuole size was linearly related to $\mathrm{Na} / \mathrm{Cl}$ concentration at leaf level (Fig. 7B, E; Table S1C) and the vacuolar allocation of contaminants indicated a direct salt accumulation effect (Fig. 4I, J). Given missing salt contaminants in cytoplasm (Fìg. 4I, J), the observed cell size increase with higher foliar salt concentrations (Fig. 7A, D; Table S1C) should be driven by that of vacuome, which was also confirmed by 1) the correlation between vacuome and cell size $(P=0.03, \mathrm{r}=0.57)$ and 2$)$ concomitant thinning and degeneration of cytoplasmic strands (Fig. 6F, L, M), as a consequence of autophagic activity (Fig. 6I, J, L, M). As indicated by non-significant models for the cell circularity (Table S1C), the cell size increased both periclinally and anticlinally. Missing cytoplasmic accumulation of salt contaminants, the observed increase in the size of chloroplasts ( $\mathrm{Cl}$ only) and plastoglobules ( $\mathrm{Na}$ only) implied an indirect driving effect of salt contaminants (Fig. 7C, F; Table S1C). Only the models calculated using leaf rim data were significant; regarding those calculated on the basis of leaf center measurements, the cross-sectional area of palisade cells formed the best responsive estimate, increasing marginally $(P=0.054 ; \mathrm{Cl})$ or as a tendency $(P=0.088 ; \mathrm{Na})$ with rising salt accumulation in foliage.

Considering the cell responses in the palisade parenchyma from leaf rim samples globally, the salt contamination matrix ( $\mathrm{Na}$ and $\mathrm{Cl}$ foliar concentrations) in the RDA model explained $78.12 \%$ of observed variation in the structural markers from descriptor matrix $(\mathrm{P}=0.001 ;$ Fig. 8$)$. However, only the first RDA axis $(77.49$ $\%)$ was significant $(P=0.001)$. The two explanatory variables showed balanced contributions. The vacuole size (VS in Fig. 8) was the structural parameter most strongly contributing to RDA axis 1 . The site centroids showed a distribution along first axis reflecting the gradient of average salt contamination in foliage. The passively projected macroscopic leaf injury parameter (Injury), which was significantly correlated with both $\mathrm{Na}$ and $\mathrm{Cl}(P<0.001$ and 0.002$)$, showed a positive correlation tendency with respect to RDA first axis $(P$ $=0.073)$.

\section{DISCUSSION}

Salt contamination and mineral nutrition in the soil rooting zone and tree foliage 
Given sampling by the end of vegetation season, the levels of salt contamination measured in the soil of Riga's street sites in September were consistent with the long-term trends and seasonal patterns of soil pollution (Cekstere \& Osvalde, 2013). The eight times-lower pollution levels of $\mathrm{Cl}$ versus Na could relate to chemical mobility and non-reactivity of $\mathrm{Cl}^{-}$anions with soil adsorption complexes, causing rapid leaching (White \& Broadley, 2001). The $\mathrm{Na}^{+} / \mathrm{Cl}^{-}$pollution levels were similar to those also recorded in September at Opole (330/170 mg kg-1, Czerniawska-Kusza et al., 2004) or in Ontario $\left(\mathrm{Na}^{+}: 51-115 \mathrm{mg} \mathrm{kg}^{-1}\right.$, Eimers et al., 2015) but inferior to those reported for the same season in Warsaw $\left(2392 / 3599 \mathrm{mg} \mathrm{dm}^{-3}\right.$, Dmuchowski et al., 2014). They were also lower than those measured in spring in Riga (724/129 $\mathrm{mg} \mathrm{kg}^{-1}$, Cekstere \& Osvalde, 2013), Toronto ( $\mathrm{Na}^{+}: 450-600 \mathrm{mg} \mathrm{kg}^{-1}$, Ordóñez-Barona et al., 2018), Moscow (517.5/480 mg kg-1, Nikolaeva et al., 2019) and Northeastern China (352-513/577-2,353 $\mathrm{mg} \mathrm{kg}^{-1}$, Fayun et al., 2015). In this one-year study, the contamination levels of $\mathrm{NaCl}$ in the soilversus lime tree foliage measured in September showed poor agreement, contrasting with earlier findings in Riga and other cities (Cekstere et al., 2008; Dmuchowski et al., 2014; Ordóñez-Barona et al., 2018). Besides the longer-term NaCl dynamic within tree organs, the discrepancy between concomitant salt leaching in the soil versusaccumulation in foliage during the vegetation season may form the main causal factor.

In addition to salt pollution, the soil conditions of street lines of lime trees were dystrophic in several other instances, with especially an alkaline $\mathrm{pH}$ and nutrient levels of $\mathrm{N}, \mathrm{K}, \mathrm{S}$ and $\mathrm{B}$ often below and those of $\mathrm{Ca}, \mathrm{Mg}, \mathrm{Fe} \mathrm{Zn}, \mathrm{Cu}$ above the sufficiency range. The main causal factors may include 1) the mostly sandy bedrock (Bouraoui et al., 2019), 2) N leaching and denitrification as frequently observed in urban conditions (Scharenbroch \& Lloyd, 2004) and 3) construction debris typical of anthroposoils enhancing the Ca, $\mathrm{Mg}$ content and promoting alkalization (Jim, 1998; Oleksyn et al., 2007; Cekstere \& Osvalde, 2013; Dmuchowski et al., 2019). The low K concentrations, below those measured in Seville (Ruiz-Cortés et al., 2005) and Moscow (Nikolaeva et al., 2019), were still higher than those recorded in Poznan (Oleksyn et al., 2007). The enhancement of $\mathrm{Fe}, \mathrm{Zn}$ and $\mathrm{Cu}$ soil content at street versus NBG sites reflected the busy urban traffic (Jim, 1998; Dmuchowski et al., 2014, Nikolaeva et al., 2019). Dystrophy trends can be worsened by salt pollution, with $\mathrm{Na}^{+}$dislodginge.g. $\mathrm{NH}^{4+}, \mathrm{K}^{+}, \mathrm{Ca}^{2+}$ or $\mathrm{Mg}^{2+}$ cations within the soil adsorption complexes (Dobson, 1991, Bryson \& Barker, 2002, Eimers et al., 2015). However, the enhanced salt concentrations did not affect the physical structure of Riga's sandy soils (Bouraoui et al., 2019). The dystrophic soil conditions in 2014 showed good agreement with previous surveys (Čekstere, 2011; Cekstere \& Osvalde, 2013).

With foliar concentrations of $\mathrm{Na}^{+} / \mathrm{Cl}^{-}$up to $13600 / 16750 \mathrm{mg} \mathrm{kg}{ }^{-1}$, the salt accumulation within Riga's lime tree foliage reached values similar to those of major macro-nutrients. Hence a main reason for the reported salt sensitivity in the Tiliagenus (Dobson, 1991, Dmuchowski et al., 2013, Sera, 2017) appears to be its poorly developed salt exclusion strategies (Munns \& Tester, 2008; Chen et al., 2018). This finding is corroborated by those on other lime tree species showing $\mathrm{NaCl}$ accumulation levels higher than in other sensitive (Paludan-Müller et al., 2002) or salt tolerant (Dmuchowski et al., 2013) ornamentals. Foliar injury threshold (1-5\% necrosis percentage area) ranging between $660-3100 / 3000-7570 \mathrm{mg} \mathrm{kg}{ }^{-1} \mathrm{Na}^{+} / \mathrm{Cl}^{-}$, in good agreement with previous findings (Čekstere, 2011), indicated higher sensitivity in Riga's lime trees versus other Tilia genus (Kopinga \& van den Burg, 1995) or salt-tolerant species (Dmuchowski et al., 2019). Such intra- and interspecific variation in salt sensitivity is of interest, with a view to selecting better-tolerant ornamentals for street greeneries.

Despite the strongly dystrophic nutritional conditions and poorly structured soil substrate of Riga's street greeneries, the nutrient balance within T. $x$ vulgaris foliage remained astonishingly well conserved. Even within infertile habitats (Chapin, 1980), the adapted plants generally achieve sustainable mineral nutrition and the Tilia genus shows a particularly large tolerance with regard to the soil type and site conditions (Radoglou et al., 2008). The sufficient ( $\mathrm{Zn}$ ) or excessive (Fe, $\mathrm{Cu}$ ) foliar concentrations of anthropogenicallyenhanced metal content in the soil were in good agreement with findings in other cities (Baycu et al., 2006; Dmuchowski et al., 2014). Mn deficiency in foliage despite a sufficient soil supply - similar to other cases of salt pollution (Dmuchowski et al., 2014), may relate to oxidation to $\mathrm{Mn}^{4+}$ forms hardly available for plants in neutral to slightly alkaline soil conditions (Marschner \& Marschner, 2012). Foliar K deficiency could result from 1) low $\mathrm{K}$ content in sandy soils, 2) dislodging from the soil adsorption complexes by $\mathrm{Na}^{+}$ 
or 3) seasonal changes (Mengel \& Kirbby, 2001). Hence, the missing negative/even paradoxically positive correlation between $\mathrm{K}$ and $\mathrm{Na} / \mathrm{Cl}$ concentration, despite the $\mathrm{Na}^{+}-\mathrm{K}^{+}$antagonism observed otherwise at tissue and cell level, may relate to complex and interfering salt, nutrient and foliage dynamics. In the case of less limited Ca supply, with opposite accumulation dynamic in foliage as compared to K (Marschner \& Marschner, 2012), the negative correlation with both $\mathrm{Na}$ and $\mathrm{Cl}$ foliar concentrations were consistent with findings at tissue and cell level.

\section{Allocation of salt contaminants to tissues and cell storage compartments in foliage}

The artefact-free microlocalization of $\mathrm{NaCl}$ contaminants within their vacuolar sinks, 1) similar to findings in studies also using cryo-microscopy (Dérue et al., 2006; James et al., 2006), 2) consistent with microscopic injury and 3) in agreement with prevailing opinion (Apse \& Blumwald, 2007; Jabeen et al., 2014; Munns et al., 2016), was conditioned to sample preparation and observation in full cryo-conditions. The high salt accumulation levels, superior in mesophyll than epidermis, suggested $\mathrm{NaCl}$ importation alongside apoplastic (epidermis) as well as symplastic (mesophyll) routes (Meidner, 1975; Leigh \& Tomos, 1993; Buckley, 2015). Superior mesophyllversus epidermis allocation has also been found in Aster tripolium (Perera et al., 1997) but contrasted with findings in cultivars of durum wheat and barley (Leigh \& Tomos, 1993; James et al., 2006). A reverse accumulation pattern was even observed in barley or halophytic Atriplex spongiosa (Fricke et al., 1996; Storey et al., in McCully et al., 2010). Massive $\mathrm{NaCl}$ allocation to stress-sensitive mesophyll suggested weak salt management at tissue level, partially explaining the reported salt stress sensitivity of lime trees. The distribution of contaminants and rate of vacuolar filling, as observed within leaf rim samples next to necrosis, exemplified situations at the far end of salt accumulation gradients within leaves. The occurrence of latter gradients was confirmed by the 1) less significant models, relating salt concentrations to microscopic changes in the leaf center versus rim samples, or 2) thickness of leaf rim necrosis varying as a function of salt concentration, similar to boron accumulation and injury patterns (Rees et al., 2011).

The $\mathrm{Na}^{+}$and $\mathrm{Cl}^{-}$contaminants showed a distribution at tissue level and microlocalization within cells similar to several mobile nutrients but a reverse dynamic. Whilst $\mathrm{K}$ is the main inorganic osmoticum in plant vacuoles, it may increasingly share this role with $\mathrm{NaCl}$ in saline conditions or in the case of a low $\mathrm{K}^{+}$ supply (Kronzucker \& Britto, 2011; Ahmad \& Maathuis, 2014; Ivanova et al., 2016), probably because of the similar Na and K physico-chemistry (Benito et al., 2014). Though the $\mathrm{Na}^{+}, \mathrm{K}^{+}$cell transporters are mostly ion-specific (Apse \& Blumwald, 2007; Ahmad \& Maathuis, 2014; Benito et al., 2014), concomitant increase of $\mathrm{Na}^{+}$and decrease of $\mathrm{K}^{+}$concentrations, as in the case of Riga's lime tree foliage, is usually observed in saline conditions (Munns et al., 2016). Steady $\mathrm{K}^{+}$concentrations and higher $\mathrm{K}^{+}: \mathrm{Na}^{+}$ratios in tolerant halophytes (Perera et al., 1997; McCully et al., 2010) let thus appear the patent mechanistic link between $\mathrm{K}^{+}$and $\mathrm{NaCl}$ dynamic within mesophyll vacuoles as another characteristic trait of salt sensitivity in lime tree (Dobson, 1991; Cekstere et al., 2008). In epidermis, especially $\mathrm{Ca}^{2+}$ but also $\mathrm{Mg}^{2+}$ formed the main cationic osmotica whilst $\mathrm{K}^{+}$played a minor role, in likely relation to ontological aging (Fricke et al., 1996). Similar to mesophyll, $\mathrm{NaCl}$ accumulation caused a drop in the concentration of inorganic osmotica, similar to observations in barley (Fricke et al., 1996) and, in this case, in line with chemical measurements at leaf level.

Besides a marked decrease of all detected nutrient mass fractions within vacuoles and replacement by $\mathrm{Na}^{+}$and $\mathrm{Cl}^{-}$ions, salt accumulation within mesophyll and epidermis tissues could also change the osmotic homeostasis. Higher vacuolar osmolarity in foliage of Riga's polluted versus NBG sites was suggested by the 1) higher $\mathrm{NaCl}$ concentrations at leaf level, 2) higher cumulated mass percentages of vacuolar ions, 3) salt-driven increase in the vacuole and cell size and 4) increased autophagic reactions. Leaves show osmotic adjustments as a function of $\mathrm{NaCl}$ exposure and osmotic pressure variation in the nutrient solution (Ottow et al., 2005). More vacuolar osmolytes can reduce osmotic stress as a consequence of increased salt concentration in the soil solution (Munns et al., 2016; Polle \& Chen, 2015) and thus alleviate physiological drought stress (Dobson, 1991).

\section{Structural responses to salt accumulation in foliage}


Notwithstanding concomitant Mn and K deficiency and likely physiological drought stress, the visible and microscopic injuries in lime tree foliage from salt-polluted street lines of Riga could be attributed to the sole effects of salt stress. Visible injury was similar to that reported in lime trees or other broadleaved species from Warsaw (Dmuchowski et al., 2013), Opole (Czerniawska-Kusza et al., 2004), London (Gibbs \& Palmer, 1994) or coastal ecosystems under salt stress (Vollenweider \& Günthardt-Goerg, 2005). Symptoms appeared partly similar to those resulting from drought stress or K deficiency but clearly distinct from Mn deficiency injury (Vollenweider \& Günthardt-Goerg, 2005; Hartmann et al., 2007; Papadakis et al., 2007). However, several microscopic traits (i.e. cell hypertrophy / normal chloroplastic grana stacks / ubiquitous starch grains) clearly excluded any significant contribution to injuries by environmental constraints other than salt stress (Fink, 1999; Vollenweider et al., 2016). Moreover, changes in the foliar concentration of $\mathrm{Na} / \mathrm{Cl}$ explained $79 \% / 65 \%$ of variation in the necrosis percentage area within leaves.

The salt-driven increase in the vacuole/cell size and microscopic injury in cytoplasm were indicative of sink adjustments and degenerative responses. Larger vacuome and cells form structural hallmarks of so-called leaf succulence trait within salt-exposed foliage (Ottow et al., 2005; Benzarti et al., 2014; Polle \& Chen, 2015). By contrast with healthy succulent plants however (e.g. Kondo et al., 1998) and as indicated by LMEM and RDA models, larges vacuoles in lime tree mesophyll did not appear for ontological reasons but resulted from phenotypic adjustments to increasing salt accumulation. Moreover, they were associated to a syndrome of typical but unspecific degenerative traits in adjacent cytoplasm (i.e. cytoplasm and organelle condensation / autophagic activity / plastoglobule size increase and extrusion into vacuoles). Indeed, most of these injuries are being observed not only in the case of salt (Hernandez et al., 1995; Naidoo et al., 2011; Yamane et al., 2012; Ivanova et al., 2016) but also ozone (Vollenweider et al., 2019) or drought stress (Fink, 1999; Vollenweider et al., 2016) or with ontological senescence (Mikkelsen \& Jorgensen, 1996; Inada et al., 1998). Similar to latter studies, they indicated an acceleration of cell senescence (ACS; Günthardt-Goerg \& Vollenweider, 2007). The lack of more specific e.g. swelling of chloroplastic thylakoids (Fink, 1999), as commonly observed during experimental salt exposure (Hernandez et al., 1995; Guan et al., 2013; Bejaoui et al., 2016), may relate to the primarily vacuolar allocation of salt contaminants. Acclimated halophytes from saline environments can also miss this trait (Naidoo et al., 2011).

The drawback of higher vacuolar osmolarity, caused by steady $\mathrm{NaCl}$ accumulation, may comprise impeded leaf conductance, leading in turn to observed ACS in synergy with disturbed hormonal balance. Mesophyll succulence-like, as a consequence of concomitant $\mathrm{NaCl}$ accumulation and autophagy, may decrease leaf conductance by reducing the circadian variation of cell volume and water exchanges (Canny \& Huang, 2006) driven by evapotranspiration and causing diel changes in the leaf thickness (Westhoff et al., 2009; Ehrenberger et al., 2012). Within epidermis and together with $\mathrm{K}^{+}, \mathrm{NO}_{3}{ }^{-}$and malate ${ }^{2-}, \mathrm{Cl}^{-}$is one of the main osmolytes which fluctuations actuate guard cell/vacuome size variation and stomatal opening (Daloso et al., 2017). Interestingly in some adapted halophytes, better salt-tolerance appear to be conferred by the lower $\mathrm{NaCl}$ and steady $\mathrm{K}^{+}$concentration to be found in guard versusepidermal neighbor cells (Perera et al., 1997; McCully et al., 2010). Furthermore, $\mathrm{Cl}^{-}>\mathrm{Na}^{+}$are abscisic acid inducers, the main hormone regulator of stomatal closure (Geilfus et al., 2018) and lower stomatal conductance forms an ecophysiological hallmark of salt stress (Munns \& Tester, 2008). Lowered stomatal conductance is consistent with enhanced senescence, as indicated by the aforementioned ACS responses (Bond, 2000, Munns \& Tester, 2008; Daszkowska-Golec \& Szarejko, 2013). Farther, it can enhance photoinhibition and photo-oxidative stress, especially in high light environment as in the outer tree canopy or at many saline habitats (Foyer et al., 1994; Suzuki et al., 2012). Enhanced oxidative stress is another consequence and hallmark of salt accumulation in foliage (Hernandez et al., 1995; Benzarti et al., 2014; Polle \& Chen, 2015), and its structural markers (Günthardt-Goerg \& Vollenweider, 2007; Moura et al., 2018) show many similarities with those observed in lime tree foliage.

\section{CONCLUSIONS}

On dystrophic anthroposoils and in increasingly warming-up and polluted urban environment of e.g. Riga's street greeneries, the large environmental tolerance of also culturally important lime tree ornamentals makes them especially suited with regard to effective ecosystem services direly needed. The studied Tilia $x$ vulgaris 
in Riga's street greeneries remediated essential nutrient deficiencies (N, S, B) or tolerated them (K, Mn) rather well, similar to the anthropogenically-enhanced metals $(\mathrm{Fe}, \mathrm{Cu})$. Their observed sensitivity to salt contamination appears to relate to 1) poor or missing exclusion uptake strategies leading to superior foliage concentration than in similarly or more tolerant ornamentals, 2) missing allocation management, with massive salt accumulation in stress-prone mesophyll and 3) substitution of $\mathrm{K}^{+}$by $\mathrm{Na}^{+}$in vacuoles, at least of mesophyll and possibly guard cell sinks. These sensitivity traits can provide improvement targets with a view to selecting more tolerant Tilia species and cultivars. Findings in this study led us to only partially validate our working hypotheses. Nutrient deficiencies in foliage primarily related to other soil pollution $(\mathrm{Mn})$ or bedrock $(\mathrm{K})$ issues, with salt pollution playing a lesser role (rejection of Hyp. 1). Within foliage, the allocation of salt contaminants primarily to mesophyll vacuoles was stress-prone at tissue (rejection of Hyp. 2a) but safe at cell (validation of Hyp. 2b) level. Structural changes in relation to storage (vacuole and cell size increase) and toxicity (ACS symptoms) reactions to foliar accumulation of salt contaminants were characteristic but not specific (partial validation of Hyp. 3). Altogether, they suggested hindrance of circadian cell size variation and evapotranspiration because of salt osmotic effects, then indirectly enhancing photoinhibition and photo-oxidative stress and promoting ACS. Direct interference by salt contamination on the water exchanges between the foliar tissues and atmosphere form a so far less frequently considered stress mechanism, which contribution to the still partly elusive $\mathrm{NaCl}$ toxicity in tree foliage may be of significant importance.

\section{CONFLICT OF INTEREST}

The authors have no conflict of interest.

\section{REFERENCES}

Ahmad I. \& Maathuis F.J.M. (2014). Cellular and tissue distribution of potassium: physiological relevance, mechanisms and regulation.Journal of Plant Physiology, 171, 708-714. doi: 10.1016/j.jplph.2013.10.016 Anonymous, 2014. Gaisa piesārņojuma mērījumu rezultāti Rīgā 2013. gadā [Measurement results of air pollution in Riga during 2013]. Rīgas dome, Mājokḷ̦u un vides departaments, Vides pārvalde, Gaisa un ūdens aizsardzības nodaļa. Apse M.P. \& Blumwald E. (2007). Na+ transport in plants. Febs Letters, 581, 2247-2254. doi.org/10.1016/j.febslet.2007.04.014 Bates D., Maechler M., Bolker B. \& Walker S. (2015). Fitting linear mixed-effects models using lme4. Journal of Statistical Software, 67(1), 1-48. doi:10.18637/jss.v067.i01 Baycu G., Doganay T., Özden H. \& Günebaken S. (2006). Ecophysiological and seasonal variations in $\mathrm{Cd}, \mathrm{Pb}, \mathrm{Zn}$, and $\mathrm{Ni}$ concentrations in the leaves of urban deciduous trees in Istambul. Environmental Pollution, 143, 545-554. DOI: 10.1016/j.envpol.2005.10.050 Bejaoui F., Salas J.J., Nouairi I., Smaoui A., Abdelly C., Martínez-Force E. \& Youssef N.B. (2016). Changes in chloroplast lipid contents and chloroplast ultrastructure in Sulla carnosa andSulla coronaria leaves under salt stress. Journal of Plant Physiology, 198, 32-38. doi.org/10.1016/j.jplph.2016.03.018 Benito B., Haro R., Amtmann A., Cuin T.A. \& Dreyer I. (2014). The twins $\mathrm{K}^{+}$and $\mathrm{Na}^{+}$in plants. Journal of Plant Physiology, 171, 723-731. doi: 10.1016/j.jplph.2013.10.014 Benzarti, M., Ben Rejeb, K.,Debez, A., Messedi, D., Abdelly, C. 2012. Photosynthetic activity and leaf antioxidative responses of Atriplex portulacoides subjected to extreme salinity. Acta Physiologiae Plantarum, 34:1679-1688. DOI 10.1007/s11738-012-0963-5 Benzarti, M., Ben Rejeb, K., Messedi, D., Ben Mna, A., Hessini, K., Ksontini, M., Abdelly, C. \& Debez, A. (2014). Effect of high salinity on Atriplex portulacoides: Growth, leaf water relations and solute accumulation in relation with osmotic adjustment. South African Journal of Botany, 95, 70-77. http://dx.doi.org/10.1016/j.sajb.2014.08.009 Bond B.J. (2000). Age-related changes in photosynthesis of woody plants. Trends in Plant Science, 5(8), 349-353. Bouraoui D., Cekstere G., Osvalde A., Vollenweider P. \& Rasmann S. (2019). Deicing salt pollution affects the foliar traits and arthropods' biodiversity of lime trees in Riga's street greeneries. Frontiers in Ecology and Evolution, 7, 282. doi.org/10.3389/fevo.2019.00282 Bryson M.G. \& Barker A.V. (2002). Sodium accumulation in soils and plants along Massachusetts roadsides. Communication 
in Soil Science and Plant Analysis, 33(1-2), 67-78. doi.org/10.1081/CSS-120002378 Buckley T.N. (2015). The contributions of apoplastic, symplastic and gas phase pathways for water transport outside the bundle sheath in leaves. Plant, Cell and Environment, 38, 7-22. doi: 10.1111/pce.12372 Canny M.J. \& Huang C.X. (2006). Leaf water content and palisade cell size. New Phytologist, 170, 75-85. doi.org/10.1111/j.1469-8137.2005.01633.x Cekstere G., Nikodemus O. \& Osvalde A. (2008). Toxic impact of the de-icing material to street greenery in Riga, Latvia. Urban Forestry and Urban Greening, 7(3), 207-217. doi.org/10.1016/j.ufug.2008.02.004 Cekstere G. \& Osvalde A. (2013). A study of chemical characteristics of soil in relation to street trees status in Riga (Latvia). Urban Forestry and Urban Greening, 12(1), 69-78. doi.org/10.1016/j.ufug.2012.09.004 Cekstere G. (2011). Environmetal Factor Influence on Common Lime (Tilia x vulgaris) Vitality in Street Greenery of Riga. Doctoral thesis. Latvia: LU Akadēmiskais apgāds. (in Latvian, with summary in English) Cekstere G., Karlsons A. \& Grauda D. (2015). Salinity-induced responses and resistance in Trifolium repens L. Urban Forestry and Urban Greening, 14(2), 225-236. doi.org/10.1016/j.ufug.2015.02.010 Chapin F.S. (1980). The mineral nutrition of wild plants. Annual Review of Ecology and Systematics, 11, 233-260. Chen M., Yang Z., Liu J., Zhu T., Wei X., Fan H. \& Wang B. (2018). Adaptation mechanism of salt excluders under saline conditions and its applications. International Journal of Molecular Sciences, 19, 3668. doi:10.3390/ijms19113668 Cunningham M.A., Snyder E., Yonkin D., Ross M. \& Elsen T. (2008). Accumulation of deicing salts in soils in an urban environment. Urban Ecosystems, 11, 17-31. DOI:10.1007/s11252007-0031-x Czerniawska-Kusza I., Kusza G. \& Duzyński, M. (2004). Effect of deicing salts on urban soils and health status of roadside trees in the Opole region. Environmental Toxicology, 19, 296-301. DOI: 10.1002/tox.20037 Daloso D.M., Medeiros D.B., dos Anjos L., Yoshida T., Araujo W.L. \& Fernie A.R. (2017). Metabolism within the specialized guard cells of plants. New Phytologist, 216, 1018-1033. doi: 10.1111/nph.14823 Daszkowska-Golec A. \& Szarejko I. (2013). Open or close the gate - stomata action under the control of phytohormones in drought stress conditions. Frontiers in Plant Science, 4, 138. doi: 10.3389/fpls.2013.00138 Dérue C., Gibouin D., Demarty M., Verdus M.C., Lefebvre F., Thellier M. \& Ripoll C. (2006). DynamicSIMS imaging and quantification of inorganic ions in frozen-hydrated plant samples. Microscopy Research and Technique, 69, 53-63. doi.org/10.1002/jemt.20270 Dmuchowski W., Baczewska A. H., Gozdowski D. \& Bragoszewska P. (2013). Effect of salt stress on the chemical composition of leaves of different trees species in urban environment. Fresenius Environmental Bulletin, 22(3), 987-994. Dmuchowski W., Baczewska A. H., Gozdowski D., Rutkowska B., Szulc W., Suwara I. \& Bragoszewska P. (2014). Effect of salt stress caused by deicing on the content of microelements in leaves of linden.Journal of Elementology, 19, 65-79. doi: 10.5601/jelem.2014.19.1.588 Dmuchowski W., Bragoszewska P., Gozdowski D., Baczewska-Dabrowska A.B., Chojnacki T., Jozwiak A., Swiezewska E., Gworek B. \& Suwara I. (2019). Strategy of Ginkgo biloba L. in the mitigation of salt stress in the urban environment. Urban Forestry $\mathcal{E}$ Urban Greening, 38, 223-231. https://doi.org/10.1016/j.ufug.2019.01.003 Dobson M.C. (1991). De-icing Salt Damage to Trees and Shrubs. UK: Forestry Commission Bulletin 101, HMSO. Ehrenberger W., Ruger S., Fitzke R., Vollenweider P., Gunthardt-Goerg M., Kuster T., Zimmermann U. \& Arend M. (2012). Concomitant dendrometer and leaf patch pressure probe measurements reveal the effect of microclimate and soil moisture on diurnal stem water and leaf turgor variations in young oak trees. Functional Plant Biology, 39, 297-305. https://doi.org/10.1071/Fp11206 Eimers M.C., Croucher K.-N., Raney S.M. \& Morris M.L. (2015). Sodium accumulation in calcareous roadside soils. Urban Ecosystems, 18(4), 1213-1225. DOI:10.1007/s11252-015-0454-8 Equiza M.A., Calvo-Polanco M., Cirelli D., Seňorans J., Wartenbe, M., Saunders, C. \& Zwiazek, J.J. (2017). Long-term impact of road salt $(\mathrm{NaCl})$ on soil and urban trees in Edmonton, Canada. Urban Forestry \& Urban Greening, 21, 16-28. https://doi.org/10.1016/j.ufug.2016.11.003 Fayun L., Ying Z., Zhiping F. \& Kokyo O. (2015). Accumulation of de-icing salts and its short-term effect on metal mobility in urban roadside soils. Bulletin of Environmental Contamination and Toxicology, 94(4), 525-531. https://doi.org/10.1007/s00128-015-1481-0 Feder N. \& O’Brien T.P. 
(1968). Plant microtechnique: some principles and new methods. American Journal of Botany, 55, 123-142. Fink S. (1999). Pathological and Regenerative Plant Anatomy. Encyclopedia of Plant Anatomy. Germany: Gebruder Borntraeger. Flowers T., Munns R., \& Colmer T.D. (2015). Sodium chloride toxicity and the cellular basis of salt tolerance in halophytes. $A n$ nals of Botany, 115, 419-431, 2015. https://doi.org/10.1093/aob/mcu217 Foyer C.H., Lelandais M. \& Kunert K.J. (1994). Photooxidative stress in plants. Physiologia Plantarum, 92, 696717. https://doi.org/10.1111/j.1399-3054.1994.tb03042.x Frey B. \& Zierold B. (2003). X-ray Microanalysis in Botanical Research. In Science, Technology and Education of Microscopy: an Overview (ed. A. Mendez-Vilas), pp. 313-324. FORMATEX, Badajoz. Fricke W., Leig R. \& Tomos A.D. (1996). The intercellular distribution of vacuolar solutes in the epidermis and mesophyll of barley leaves changes in response to NaCl. Journal of Experimental Botany, 47(302), 14131426. Geilfus C.M., Ludwig-Muller J., Bardos G. \& Zorb C. (2018). Early response to salt ions in maize (Zea mays L.). Journal of Plant Physiology, 220, 173-180. doi: 10.1016/j.jplph.2017.11.010 Gibbs J.N. \& Palmer C.A. (1994). A survey of damage to roadside trees in London caused by the application of de-icing salt during the 1990/1991 winter. Arboricultural Journal, 18, 321-343. Guan Z.Y., Su Y.J., Teng N.J., Chen S.M., Sun H.N., Li C.L. \& Chen F.D. (2013). Morphological, physiological, and structural responses of two species of Artemisia to NaCl stress. Scientific World Journal, 309808. doi: 10.1155/2013/309808 Günthardt-Goerg M.S. \& Vollenweider P. (2007). Linking stress with macroscopic and microscopic leaf response in trees: new diagnostic perspectives. Environmental Pollution, 147(3), 467-488. doi:10.1016/j.envpol.2006.08.033. Hartmann G., Nienhaus F. \& Butin H. (2007). Farbatlas Waldschäden. 3. Auflage. Diagnose von Baumkrankheiten. 3. Auflage. EugenUlmer KG, Stuttgart. Hernandez J.A., Olmos E., Corpas F.J., Sevilla F. \& Delrio L.A. (1995). Salt-induced oxidative stress in chloroplasts of pea-plants. Plant Science, 105, 151-167. Huang C.X. \& van Steveninck, R.F.M. (1989). Maintenance of low $\mathrm{Cl}^{-}$concentrations in mesophyll cells of leaf blades of barley seedlings exposed to salt stress. Plant Physiology, 90, 1440-1443. IUSS Working Group WRB, 2014. World Reference Base for Soil Resources 2014. International Soil Classification System for Naming Soils and Creating Legends for Soil Maps (PDF) (3rd ed.). Rome: FAO. Ivanova T.V., Maiorova O.V., Orlova Y.V., Kuznetsova E.I., Khalilova L.A., Myasoedov N.A., Balnokin Y.V. \& Tsydendambaev V.D. (2016). Cell ultrastructure and fatty acid composition of lipids in vegetative organs of Chenopodium album L. under salt stress conditions.Russian Journal of Plant Physiology, 63(6), 763-775. doi.org/10.1134/S1021443716060054 Jabeen Z., Hussain N., Han Y., Shah M. J., Zeng F., Zeng J. \& Zhang G. (2014). The differences in physiological responses, ultrastructure changes, and $\mathrm{Na}^{+}$subcellular distribution under salt stress among the barley genotypes differing in salt tolerance.Acta Physiologiae Plantarum, 36, 2397-2407. DOI:10.1007/s11738-014-1613-x Jaeger B. (2017). r2glmm: Computes R Squared for Mixed (Multilevel) Models. R package version 0.1.2. https://CRAN.R-project.org/package=r2glmm James R.A., Munns R., Von Caemmerer S., Trejo C., Miller C. \& Condon T. (2006). Photosynthetic capacity is related to the cellular and subcellular partitioning of $\mathrm{Na}^{+}, \mathrm{K}^{+}$and $\mathrm{Cl}^{-}$in salt-affected barley and durum wheat.Plant Cell and Environment, 29, 2185-2197. doi.org/10.1111/j.1365-3040.2006.01592.x Jim C.Y. (1998). Physical and chemical properties of a Hong Kong roadside soil in relation to urban tree growth. Urban Ecosystems, 2, 171-181. Ke C., Li Z., Liang Y., Tao W. \& Du M. (2013). Impacts of chloride de-icing salt on bulk soils, fungi, and bacterial populations surrounding the plant rhizosphere. Applied Soil Ecology, 72, 69-78. doi.org/10.1016/j.apsoil.2013.06.003 Kondo A., Nose A. \& Ueno O. (1998). Leaf inner structure and immunogold localization of some key enzymes involved in carbon metabolism in CAM plants. Journal of Experimental Botany, 49, 1953-1961. doi.org/10.1093/jxb/49.329.1953 Kopinga J. \& van den Burg J. (1995). Using soil and foliar analysis to diagnose the nutritional status of urban trees. Journal of Arboriculture, 21(1), 17-23. Kronzucker H.J. \& Britto D.T. (2011). Sodium transport in plants: a critical review. New Phytologist, 189, 54-81. doi.org/10.1111/j.1469-8137.2010.03540.x Kubínová L. (1994). Recent stereological methods for measuring leaf anatomical characteristics: estimation of the number and 
sizes of stomata and mesophyll cell. Journal of Experimental Botany, 45, 119-127. Leigh R.A. \& Tomos A.D. (1993). Ion distribution in cereal leaves - pathways and mechanisms. Philosophical Transactions of the Royal Society of London Series B-Biological Sciences, 341, 75-86. Li B., Tester M. \& Gilliham M. (2017). Chloride on the move.Trends in Plant Science, 22(3), 236-248. http://dx.doi.org/10.1016/j.tplants.2016.12.004 Marosz A. (2011). Soil pH, electrical conductivity values and roadside leaf sodium concentration at three sites in central Poland.Dendrobiology, 66, 49-54. Marschner H. \& Marschner P. (2012). Marschner's Mineral Nutrition of Higher Plants, $3^{\text {rd }}$ ed. London: Elsevier/Academic Press; Waltham, MA. McCully M.E., Canny M.J., Huang C.X., Miller C. \& Brink F. (2010). Cryo-scanning electron microscopy (CSEM) in the advancement of functional plant biology: energy dispersive X-ray microanalysis (CEDX) applications. Functional Plant Biology, 37, 1011-1040. doi.org/10.1071/FP10095 Meidner H. (1975). Water supply, evaporation, and vapor diffusion in leaves. Journal of Experimental Botany, 26, 666-673. Mengel K. \& Kirkby E.A. (2001). Principles of Plant Nutrition. 5th edn. The Netherlands: Kluwer Academic Publishers. Mikkelsen T.N. \& Heide Jorgensen H.S. (1996). Acceleration of leaf senescence in Fagus sylvatica L by low levels of tropospheric ozone demonstrated by leaf colour, chlorophyll fluorescence and chloroplast ultrastructure. Trees-Structure and Function, 10, 145-156. Milewska-Hendel A., Baczewska A.H., Sala K., Dmuchowski W., Bragoszewska P., Gozdowski D., Jozwiak A., Chojnacki T., Swiezewska E. \& Kurczynska E. (2017). Quantitative and qualitative characteristics of cell wall components and prenyl lipids in the leaves of Tilia $x$ euchloratrees growing under salt stress. PLoS One, 12(2), e0172682. doi: 10.1371/journal.pone.0172682. Moser A., Rötzer T., Pauleit S. \& Pretzsch H. (2015). Structure and ecosystem services of small-leaved lime (Tilia cordata Mill.) and black locust (Robinia pseudoacacia L.) in urban environments. Urban Forestry \& Urban Greening, 14, 1110-1121. doi.org/10.1016/j.ufug.2015.10.005 Motsara M.R. \& Roy R.N. (2008). Guide to Laboratory Establishment for Plant Nutrient Analysis. FAO Fertilizer and Plant Nutrition Bulletin 19. Italy: FAO. Moura B.B., Alves E.S., Marabesi M.A., de Souza S.R., Schaub M. \& Vollenweider P. (2018). Ozone affects leaf physiology and causes injury to foliage of native tree species from the tropical Atlantic Forest of southern Brazil. Science of the Total Environment, 610, 912-925. doi.org/10.1016/j.scitotenv.2017.08.130 Munns R., James R.A., Gilliham M., Flowers T.J. \& Colmer T.D. (2016). Tissue tolerance: an essential but elusive trait for salt-tolerant crops. Functional Plant Biology, 43, 1103-1113. doi.org/10.1071/FP16187 Munns R. \& Tester M. (2008). Mechanisms of salinity tolerance.Annual Reviews of Plant Biology, 59, 651-681. doi.org/10.1146/annurev.arplant.59.032607.092911 Muszynska A., Jarocka K. \& Kurczynska E.U. (2014). Plasma membrane and cell wall properties of an aspen hybrid (Populus tremula $x$ tremuloides) parenchyma cells under the influence of salt stress.Acta Physiologiae Plantarum, 36, 1155-1165. doi.org/10.1007/s11738-014-1490-3 Naidoo G., Hiralal O. \& Naidoo Y. (2011). Hypersalinity effects on leaf ultrastructure and physiology in the mangrove Avicennia marina.Flora, 206, 814-820. /doi.org/10.1016/j.flora.2011.04.009 Negrão S., Schmöckel S.M. \& Tester M. (2017). Evaluating physiological responses of plants to salinity stress. $A n$ nals of Botany, 119(1), 1-11. doi:10.1093/aob/mcw191. Nikodemus O., Zvirgzds A., Cekule M., Cekstere G., Granta D. \& Šveisberga I. (2003). Greenery in the historic centre of Riga and its role in improving urban environmental quality. In Environment and Sustainability Profile for Riga (ed. L. Osis), pp. 23-29. Riga City Environment Centre "Agenda 21", Riga. Nikolaeva O., Tikhonov V., Vecherskii M., Kostina N., Fedoseeva E. \& Astaikina A. (2019). Ecotoxicological effects of traffic-related pollutants in roadside soils of Moscow. Ecotoxicology and Environmental Safety, 172, 538-546. https://doi.org/10.1016/j.ecoenv.2019.01.068 Nowak D. J., Hirabayashi S., Doyle M., McGovern M. \& Pasher J. (2017). Air pollution removal by urban forests in Canada and its effect on air quality and human health. Urban Forestry 8 Urban Greening, 29, 40-48. doi.org/10.1016/j.ufug.2017.10.019 Oksanen J., Blanchet F.G., Friendly M., Kindt R., Legendre P., McGlinn D., Minchin P.R., O'Hara R.B., Simpson G.L., Solymos P., Stevens M.H.H., Szoecs E. \& Wagner H. (2017). Vegan: Community Ecology Package. R package version 2.4-4. https://CRAN.R-project.org/package=vegan Oleksyn J., Kloeppel B.D., 
Lukasiewicz S., Karolewski P. \& Reich P.B. (2007). Ecophysiology of horse chestnut (Aesculus hippocastanumL.) in degraded and restored urban sites. Polish Journal of Ecology, 55, 245-260. Ordóñez-Barona C., Sabetski V., Millward A.A. \& Steenberg J. (2018). De-icing salt contamination reduces urban tree performance in structural soil cells. Environmental Pollution, 234, 562-571. doi.org/10.1016/j.envpol.2017.11.101 Osvalde A. (2011). Optimization of plant mineral nutrition revisited: the roles of plant requirements, nutrient interactions, and soil properties in fertilization management. Environmental and Experimental Biology, 9, 1-8. Ottow E.A., Brinker M., Teichmann T., Fritz E., Kaiser W., Brosché M., Kangasjärvi J., Jiang X. \& Polle A. (2005). Populus euphratica displays apoplastic sodium accumulation, osmotic adjustment by decreases in calcium and soluble carbohydrates, and develops leaf succulence under salt stress. Plant Physiology, 139, 1762-1772. doi.org/10.1104/pp.105.069971 Paludan-Müller G., Saxe H., Pedersen L.B. \& Randrup T.B. (2002). Differences in salt sensitivity of four deciduous tree species to soil or airborne salt. Physiologia Plantarum, 114, 223-230. Papadakis I.E., Bosabalidis A.M., Sotiropoulos T.E. \& Therios I.N. (2007). Leaf anatomy and chloroplast ultrastructure of Mn-deficient orange plants. Acta Physiologiae Plantarum, 29, 297-301. DOI 10.1007/s11738-007-0038-1 Pedersen L.B., Randrup T.B. \& Ingerslev B. (2000). Effects of road distance and protective measures on deicing $\mathrm{NaCl}$ deposition and soil solution chemistry in planted median strips. Journal of Arboriculture, 26, 238-245. Perera L.K.R.R., De Silva D.L.R. \& Mansfield T.A. (1997). Avoidance of sodium accumulation by the stomatal guard cells of the halophyteAster tripolium. Journal of Experimental Botany, 48(308), 707-711. Polle A. \& Chen S.L. (2015). On the salty side of life: molecular, physiological and anatomical adaptation and acclimation of trees to extreme habitats. Plant Cell and Environment, 38, 1794-1816. doi.org/10.1111/pce.12440 R Core Team (2017). R: A Language and Environment for Statistical Computing. R Foundation for Statistical Computing. Vienna, Austria. URL https://www.R-project.org/. Radoglou K., Dobrowolska D., Spyroglou G. \& Nicolescu V.N. (2009). A review on the ecology and silviculture of limes (Tilia cordataMill., Tilia platyphyllos Scop. and Tilia tomentosaMoench.) in Europe. Die Bodenkultur, 60(3), 9-19. Rees R., Robinson B.H., Menon M., Lehmann E., Gunthardt-Goerg M.S. \& Schulin R. (2011). Boron accumulation and toxicity in hybrid poplar (Populus nigra x euramericana). Environmental Science \& Technology, 45, 10538-10543. doi.org/10.1021/es201100b Rinkis G.J., Ramane H.K. \& Kunickaya T.A. (1987). Metodi analiza pochv i rasteniy (Methods of soil and plant analysis). Riga: Zinatne. (in Russian) Rokebul Anower M., Peel M.D., Mott I.W. \& Wu Y. (2017). Physiological processes associated with salinity tolerance in an alfalfa half-sib family. Journal of Agronomy and Crop Science, 203, 506-518. https://doi.org/10.1111/jac.12221 Ruiz-Cortés E., Reinoso R., Díaz-Barrientos E. \& Madrid L. (2005). Concentrations of potentially toxic metals in urban soils of Seville: relationship with different land uses. Environmental Geochemistry and Health, 27, 465-474. doi.org/10.1007/s10653-005-4222-1 Scharenbroch B.C. \& Lloyd J.E. (2004). A literature review of nitrogen availability indices for use in urban landscape. Journal of Arboriculture, 30, 214-229. Sera B. (2017). Salt-tolerant trees usable for Central European cities - A review. Horticultural Science, 44(1), 43-48. doi.org/10.17221/201/2015-HORTSCI Suzuki N., Koussevitzky S., Mittler R. \& Miller G. (2012). ROS and redox signalling in the response of plants to abiotic stress.Plant Cell and Environment, 35, 259-270. doi.org/10.1111/j.1365-3040.2011.02336.x Toth R. (1982). An introduction to morphometric cytology and its application to botanical research. American Journal of Botany,69(10), 1694-1706. Vollenweider P. \& Günthardt-Goerg M.S. (2005). Diagnosis of abiotic and biotic stress factors using the visible symptoms in the foliage.Environmental Pollution, 137(3), 455-465. doi.org/10.1016/j.envpol.2005.01.032 Vollenweider, P., Gunthardt-Goerg, M.S., Menard, T., Baumgarten, M., Matyssek, R. \& Schaub, M. (2019). Macro- and microscopic leaf injury triggered by ozone stress in beech foliage (Fagus sylvatica L.).Annals of Forest Science, 76, 71. doi.org/10.1007/s13595-019-0856-5 Vollenweider P., Menard T., Arend M., Kuster T.M. \& Gunthardt-Goerg M.S. (2016). Structural changes associated with drought stress symptoms in foliage of Central European oaks. Trees-Structure and Function, 30, 883-900. doi.org/10.1007/s00468-015-1329-6 Westhoff M., Reuss R., Zimmermann D., Netzer Y., 
Gessner A., Gessner P., Zimmermann G., Wegner L.H., Bamberg E., Schwartz A. \& Zimmermann U. (2009). A non-invasive probe for online-monitoring of turgor pressure changes under field conditions. Plant Biology, 11(5), 701-712. doi.org/10.1111/j.1438-8677.2008.00170.x White P.J. \& Broadley M.R. (2001). Chloride in soils and its uptake and movement within the plant: a review. Annals of Botany, 88, 967-988. doi: 10.1006/anbo.2001.1540 Wu B. \& Becker J.S. (2012). Imaging techniques for elements and element species in plant science. Metallomics, 4, 403-416. DOI: $10.1039 / \mathrm{c} 2 \mathrm{mt} 00002 \mathrm{~d} \mathrm{Wu} \mathrm{H}$. (2018). Plant salt tolerance and $\mathrm{Na}^{+}$sensing and transport. The Crop Journal, 6, 215-225. doi.org/10.1016/j.cj.2018.01.003 Yamane K., Mitsuya S., Taniguchi M. \& Miyake H. (2012). Salt-induced chloroplast protrusion is the process of exclusion of ribulose-1,5-bisphosphate carboxylase/oxygenase from chloroplasts into cytoplasm in leaves of rice. Plant Cell and Environment, 35(9), 1663-1671. doi.org/10.1111/j.1365-3040.2012.02516.x

Table 1. Seasonal and annual climate conditions in Riga during the 1997-2016 reference period. Source: Latvian Environment, Geology and Meteorology Centre (state limited liability)

\begin{tabular}{llllll}
\hline Parameter & Winter (DJF) & Spring (MAM) & Summer (JJA) & Autumn (SON) & Annual \\
\hline Mean precipitation $(\mathrm{mm})$ & 126 & 117 & 247 & 195 & 685 \\
Mean temperature $\left({ }^{\circ} \mathrm{C}\right)$ & -1.7 & 7.6 & 18.7 & 8.2 & 8.2 \\
Mean daily minimum $\left({ }^{\circ} \mathrm{C}\right)$ & -4.1 & 3.4 & 14.2 & 5.4 & 4.7 \\
Mean daily maximum $\left({ }^{\circ} \mathrm{C}\right)$ & 0.3 & 11.7 & 22.8 & 10.8 & 11.4 \\
Amount of days with freezing temperatures & 59 & 20 & 0 & 11 & 90 \\
\hline
\end{tabular}

Table 2. Macro/micronutrient content and $\mathrm{pH}_{\mathrm{KCl}}$ of soils in the rooting zone of Tilia $x$ vulgaris trees from the selected street line sites of Riga's street greenery (September 16, 2014). The sites are arranged in the Table according to the increasing salt contamination in foliage. The values (mean $+\mathrm{SE}, \mathrm{N}=3$ ) below (....) and above ( .) the sufficiency range for deciduous trees are outlined. For elements showing significantly different values between sites (one-way ANOVA, $P<0.05$ ), the significant contrasts between sites are specified using different letters (Tukey's post-hoc test, $P<0.05$ )

\begin{tabular}{|c|c|c|c|c|c|c|c|}
\hline & NBG & Meierovica 2 & Valdemara & Meierovica 1 & Barona & Hanzas & Gertrudes \\
\hline$\left(\mathrm{mg} \mathrm{kg}^{-1}\right)$ & $39.8 \pm 2.1 \mathrm{c}$ & $34.0 \pm 1.5 \mathrm{c}$ & $9.7 \pm 0.2 \mathrm{a}$ & $7.9 \pm 6.3 \mathrm{c}$ & $28.0 \pm 2$. & $39.9 \pm 3.7 \mathrm{c}$ & $.2 \pm 6.8$ \\
\hline$\left(\mathrm{mg} \mathrm{kg}^{-1}\right)$ & & $0.6 \pm 25.7 \mathrm{~b}$ & $279.4 \pm 7.1 \mathrm{a}$ & $5.6 \pm 39.8 \mathrm{bc}$ & $4.5 \pm 31.6 \mathrm{a}$ & $76.4 \pm 12.9 \mathrm{bc}$ & $9.2 \pm 51$ \\
\hline $\mathrm{K}\left(\mathrm{mg} \mathrm{kg}{ }^{-1}\right)$ & $172.0 \pm 8.2 \mathrm{~b}$ & $143.8 \pm 9.5 \mathrm{~b}$ & $120.9 \pm 10.5 \mathrm{~b}$ & $173.7 \pm 21.7 \mathrm{~b}$ & $15.4 \pm 17.4 \mathrm{c}$ & $77.3 \pm 0.8 \mathrm{a}$ & \\
\hline $\mathrm{Ca}\left(\mathrm{mg} \mathrm{kg}^{-1}\right)$ & $6048 \pm 395$ a & $4679 \pm 298 \mathrm{a}$ & $22951 \pm 358 \mathrm{c}$ & $8374 \pm 712 \mathrm{ab}$ & $35606 \pm 2354 \mathrm{~d}$ & $13081 \pm 921 \mathrm{~b}$ & \\
\hline $\operatorname{Mg}\left(\mathrm{mg} \mathrm{kg}^{-1}\right)$ & $2280 \pm 281 \mathrm{a}$ & $1625 \pm 193 \mathrm{a}$ & $5612 \pm 151 \mathrm{~b}$ & $2862 \pm 371 \mathrm{a}$ & $24270 \pm 1739 \mathrm{c}$ & $3658 \pm 73$ ab & $35 \pm 799$ \\
\hline $\mathrm{S}\left(\mathrm{mg} \mathrm{kg}^{-1}\right)$ & $14.3 \pm 0.6 \mathrm{a}$ & $11.9 \pm 0.4 \mathrm{a}$ & $16.1 \pm 2.5 \mathrm{a}$ & $13.7 \pm 0.4 \mathrm{a}$ & $18.3 \pm 0$. & $22.0 \pm 0.3 \mathrm{ab}$ & $30.5 \pm 9.2$ \\
\hline $\mathrm{Fe}\left(\mathrm{mg} \mathrm{kg}^{-1}\right)$ & $712 \pm 3$ & & & $2467 \pm 452 \mathrm{~b}$ & $06 \mathrm{~b}$ & $2796 \pm 173 \mathrm{~b}$ & $1299 \pm 160$ \\
\hline $\operatorname{Mn}\left(\mathrm{mg} \mathrm{kg}^{-1}\right)$ & $92.0 \pm$ & & & $22.2 \mathrm{a}$ & $230.0=$ & $162.7 \pm 4.4 \mathrm{~b}$ & $116.8 \pm 1$ \\
\hline $\mathrm{Zn}\left(\mathrm{mg} \mathrm{kg}^{-1}\right)$ & $7.3 \pm 0$ & $20.9 \pm$ & 62.9 & & $221.2=$ & $211.1 \pm 100.3 \mathrm{~d}$ & $119.0 \pm 2$ \\
\hline $\mathrm{Cu}\left(\mathrm{mg} \mathrm{kg}^{-1}\right)$ & $2.5 \pm 1$ & $11.6 \pm$ & $75.5=$ & $60.4 \pm 10.4 \mathrm{~d}$ & $67.5 \pm 11.4 \mathrm{~d}$ & $24.3 \pm 1.0 \mathrm{c}$ & $23.9 \pm 4$. \\
\hline Mo $\left(\mathrm{mg} \mathrm{kg}^{-1}\right)$ & $0.04 \pm$ & $0.06 \pm 0.01 \mathrm{ab}$ & & & $0.03 \pm 0.00 \mathrm{a}$ & $0.11 \pm 0.01 \mathrm{c}$ & $0.06 \pm 0.01$ \\
\hline $\mathrm{B}\left(\mathrm{mg} \mathrm{kg}^{-1}\right)$ & $0.14 \pm 0.03 \mathrm{a}$ & $0.22 \pm 0.03 \mathrm{a}$ & $0.09 \pm 0.00 \mathrm{a}$ & & & $0.47 \pm 0.06 \mathrm{~b}$ & $0.21 \pm 0.0$ \\
\hline $\mathrm{pH}_{\mathrm{KCl}}$ & $6.76 \pm 0.02 \mathrm{a}$ & $6.77 \pm 0.06 \mathrm{a}$ & $7.21 \pm 0.01 \mathrm{~b}$ & $6.75 \pm 0.06 \mathrm{a}$ & $7.16 \pm 0.08 \mathrm{~b}$ & $6.64 \pm 0.01 \mathrm{a}$ & $7.29 \pm 0.0$ \\
\hline
\end{tabular}

* According to Nollendorfs (unpublished compilation), Bergmann (1988), Čekstere (2011), Čekstere and Osvalde (2013) and Cekstere et al. (2016)

Table 3. Macro and micronutrient content in foliage of Tilia $x$ vulgaris trees from the selected street line sites of Riga's street greenery (September 16, 2014). The sites are arranged in the Table according to the 
increasing salt contamination in foliage. The values (mean $+\mathrm{SE}, \mathrm{N}=3$ ) below the (....) and above ( .) the sufficiency range for deciduous trees are outlined. For elements showing significantly different values between sites (one-way ANOVA, $P<0.05$ ), the significant contrasts between sites are specified using different letters (Tukey's post-hoc test, $P<0.05$ )

\begin{tabular}{lllllll}
\hline & NBG & Meierovica 2 & Valdemara & Meierovica 1 & Barona & Hanzas \\
\hline $\mathrm{N}(\%)$ & $1.91 \pm 0.08 \mathrm{a}$ & $1.94 \pm 0.10 \mathrm{a}$ & $2.03 \pm 0.05 \mathrm{a}$ & $2.04 \pm 0.18 \mathrm{a}$ & $2.15 \pm 0.09 \mathrm{a}$ & $1.86 \pm 0.06 \mathrm{a}$ \\
$\mathrm{P}(\%)$ & $0.23 \pm 0.00 \mathrm{a}$ & $0.30 \pm 0.00 \mathrm{~b}$ & $0.22 \pm 0.00 \mathrm{a}$ & $0.31 \pm 0.03 \mathrm{ab}$ & $0.30 \pm 0.03 \mathrm{~b}$ & $0.23 \pm 0.03 \mathrm{a}$ \\
$\mathrm{K}(\%)$ & $0.93 \pm 0.08 \mathrm{bc}$ & $1.33 \pm 0.06 \mathrm{c}$ & $0.89 \pm 0.19 \mathrm{~b}$ & $0.43 \pm 0.05 \mathrm{a}$ & $1.18 \pm 0.29 \mathrm{cb}$ & $0.32 \pm 0.01 \mathrm{a}$ \\
$\mathrm{Ca}(\%)$ & $1.85 \pm 0.08 \mathrm{~b}$ & $2.03 \pm 0.08 \mathrm{~b}$ & $1.55 \pm 0.07 \mathrm{a}$ & $1.97 \pm 0.14 \mathrm{~b}$ & $1.47 \pm 0.13 \mathrm{a}$ & $1.55 \pm 0.07 \mathrm{a}$ \\
$\mathrm{Mg}(\%)$ & $0.41 \pm 0.04 \mathrm{a}$ & $0.54 \pm 0.04 \mathrm{ab}$ & $0.39 \pm 0.04 \mathrm{a}$ & $0.73 \pm 0.10 \mathrm{~b}$ & $0.38 \pm 0.02 \mathrm{a}$ & $0.45 \pm 0.06 \mathrm{a}$ \\
$\mathrm{S}(\%)$ & $0.14 \pm 0.00 \mathrm{a}$ & $0.15 \pm 0.01 \mathrm{a}$ & $0.15 \pm 0.01 \mathrm{a}$ & $0.14 \pm 0.01 \mathrm{a}$ & $0.15 \pm 0.00 \mathrm{a}$ & $0.14 \pm 0.01 \mathrm{a}$ \\
$\mathrm{Fe}\left(\mathrm{mg} \mathrm{kg}^{-1}\right)$ & $122.00 \pm 9.87 \mathrm{a}$ & $493.33 \pm 40.55 \mathrm{~cd}$ & $433.33 \pm 46.67 \mathrm{c}$ & $366.67 \pm 17.64 \mathrm{bc}$ & $520.00 \pm 69.28 \mathrm{~d}$ & $446.67 \pm 40.55 \mathrm{~cd}$ \\
$\mathrm{Mn}\left(\mathrm{mg} \mathrm{kg}^{-1}\right)$ & $17.53 \pm 2.27 \mathrm{a}$ & $27.33 \pm 1.76 \mathrm{~b}$ & $18.27 \pm 1.44 \mathrm{a}$ & $16.13 \pm 0.82 \mathrm{a}$ & $22.00 \pm 1.15 \mathrm{a}$ & $28.67 \pm 0.67 \mathrm{~b}$ \\
$\mathrm{Zn}\left(\mathrm{mg} \mathrm{kg}^{-1}\right)$ & $15.73 \pm 0.81 \mathrm{a}$ & $21.33 \pm 0.67 \mathrm{ab}$ & $23.33 \pm 2.40 \mathrm{ab}$ & $20.67 \pm 0.67 \mathrm{a}$ & $25.33 \pm 3.53 \mathrm{~b}$ & $28.67 \pm 1.76 \mathrm{~b}$ \\
$\mathrm{Cu}\left(\mathrm{mg} \mathrm{kg}^{-1}\right)$ & $6.20 \pm 0.12 \mathrm{a}$ & $15.07 \pm 1.44 \mathrm{~b}$ & $44.67 \pm 6.67 \mathrm{c}$ & $10.20 \pm 0.61 \mathrm{~b}$ & $14.40 \pm 1.40 \mathrm{~b}$ & $12.73 \pm 1.22 \mathrm{~b}$ \\
$\mathrm{Mo}\left(\mathrm{mg} \mathrm{kg}^{-1}\right)$ & $0.37 \pm 0.04 \mathrm{a}$ & $0.91 \pm 0.10 \mathrm{~b}$ & $0.78 \pm 0.06 \mathrm{~b}$ & $1.67 \pm 0.44 \mathrm{c}$ & $1.90 \pm 0.30 \mathrm{c}$ & $1.32 \pm 0.27 \mathrm{c}$ \\
$\mathrm{B}\left(\mathrm{mg} \mathrm{kg}^{-1}\right)$ & $23.00 \pm 2.89 \mathrm{ab}$ & $22.33 \pm 1.67 \mathrm{a}$ & $24.67 \pm 1.76 \mathrm{ab}$ & $27.00 \pm 1.53 \mathrm{~b}$ & $25.33 \pm 1.20 \mathrm{ab}$ & $23.33 \pm 2.73 \mathrm{ab}$ \\
\hline
\end{tabular}

* According to Nollendorfs (unpublished compilation), Bergmann (1988), Čekstere (2011) and Cekstere et al. (2016)

Table S1. Main effects of $\mathrm{Na}$ and $\mathrm{Cl}$ accumulation on plant nutrients (A), leaf injury (B) and cell structure (C) within foliage of Tilia $x$ vulgaris trees from the street greenery of Riga. Within LMEM models, the site was treated as a random factor. The significant models (p[?]0.05) are outlined using bold characters. The "Estimate" values provide indication on $\mathrm{Na}, \mathrm{Cl}$ factor positive or negative effect $(\mathrm{n}=24$ for plant nutrients, leaf injury and LM; n=15 for TEM).

\begin{tabular}{|c|c|c|c|c|c|c|c|c|c|}
\hline Parameter & $\mathrm{Na}$, leaves & $\mathrm{Na}$, leaves & $\mathrm{Na}$, leaves & $\mathrm{Na}$, leaves & & $\mathrm{Cl}$, leaves & & & \\
\hline & Estimate & $\mathrm{t}$-value & $\mathrm{p}$ & $\mathrm{R}^{2}$ & $\mathrm{R}^{2}$ & Estimate & t-value & $\mathrm{p}$ & $\mathrm{R}^{2}$ \\
\hline \multicolumn{9}{|l|}{ A Plant nutrients } & 0.002 \\
\hline $\mathrm{P}$ & 0.001 & 0.025 & 0.981 & $<0.001$ & $<0.001$ & 0.010 & 0.881 & 0.388 & 0.076 \\
\hline K & -0.111 & -1.087 & 0.293 & 0.121 & 0.121 & 0.263 & 2.991 & 0.007 & 0.486 \\
\hline $\mathrm{Ca}$ & -0.183 & -2.995 & 0.011 & 0.482 & 0.482 & -0.151 & -2.421 & 0.026 & 0.374 \\
\hline $\mathrm{Mg}$ & -0.341 & -0.927 & 0.367 & 0.092 & 0.092 & -0.004 & -0.127 & 0.900 & 0.002 \\
\hline S & -0.006 & -1.805 & 0.101 & 0.218 & 0.218 & -0.001 & -0.105 & 0.918 & $<0.001$ \\
\hline $\mathrm{Fe}$ & 35.912 & 1.166 & 0.256 & 0.151 & 0.151 & 78.397 & 3.323 & 0.003 & 0.542 \\
\hline Mn & 0.771 & 0.527 & 0.607 & 0.028 & 0.028 & 0.548 & 0.388 & 0.703 & 0.014 \\
\hline $\mathrm{Zn}$ & 2.901 & 3.288 & 0.009 & 0.485 & 0.485 & 3.382 & 4.028 & $<0.001$ & 0.623 \\
\hline $\mathrm{Cu}$ & -0.014 & -0.006 & 0.995 & $<0.001$ & $<0.001$ & 3.820 & 2.210 & 0.040 & 0.308 \\
\hline Mo & 0.272 & 1.857 & 0.081 & 0.283 & 0.283 & 0.319 & 2.552 & 0.024 & 0.370 \\
\hline B & -1.910 & -2.011 & 0.068 & 0.277 & 0.277 & -0.968 & -0.988 & 0.340 & 0.080 \\
\hline B Leaf injury & 4.130 & 1.466 & 0.159 & 0.194 & 0.194 & 0.593 & 0.238 & 0.815 & 0.005 \\
\hline \multicolumn{10}{|l|}{ C Cell structure } \\
\hline Leaf centre, LM & & & & & & & & & \\
\hline Area, $\mathrm{pP}$ & 37.610 & 1.868 & 0.088 & 0.243 & 0.243 & 39.686 & 2.125 & 0.054 & 0.270 \\
\hline Perimeter, pP & 4.900 & 1.470 & 0.168 & 0.171 & 0.171 & 4.481 & 1.383 & 0.188 & 0.146 \\
\hline Length, pP & 2.172 & 1.402 & 0.186 & 0.161 & 0.161 & 2.035 & 1.359 & 0.195 & 0.144 \\
\hline Width, pP & 0.191 & 0.594 & 0.558 & 0.022 & 0.022 & 0.205 & 0.640 & 0.529 & 0.025 \\
\hline
\end{tabular}




\begin{tabular}{llllllllll}
\hline Parameter & $\mathrm{Na}$, leaves & $\mathrm{Na}$, leaves & $\mathrm{Na}$, leaves & $\mathrm{Na}$, leaves & \multicolumn{3}{c}{$\mathrm{Cl}$, leaves } \\
\hline $\begin{array}{l}\text { Circularity, pP } \\
\text { Leaf rim, LM }\end{array}$ & 0.002 & 0.150 & 0.882 & 0.003 & 0.003 & 0.011 & 0.948 & 0.356 & 0.080 \\
Area, pP cells & $\mathbf{4 5 . 8 2 1}$ & $\mathbf{4 . 3 5 9}$ & $\mathbf{0 . 0 0 1}$ & $\mathbf{0 . 6 2 2}$ & $\mathbf{0 . 6 2 2}$ & $\mathbf{4 0 . 7 7 8}$ & $\mathbf{3 . 6 2 9}$ & $\mathbf{0 . 0 0 3}$ & $\mathbf{0 . 5 3 4}$ \\
Perimeter, pP cells & $\mathbf{6 . 8 9 8}$ & $\mathbf{2 . 4 1 5}$ & $\mathbf{0 . 0 3 7}$ & $\mathbf{0 . 3 2 1}$ & $\mathbf{0 . 3 2 1}$ & $\mathbf{7 . 0 3 2}$ & $\mathbf{2 . 5 7 4}$ & $\mathbf{0 . 0 2 5}$ & $\mathbf{0 . 3 3 5}$ \\
Length, pP cells & 3.042 & 2.168 & 0.054 & 0.288 & 0.288 & 2.818 & 2.053 & 0.062 & 0.254 \\
Width, pP cells & $\mathbf{0 . 7 0 6}$ & $\mathbf{2 . 3 9 0}$ & $\mathbf{0 . 0 2 6}$ & $\mathbf{0 . 2 6 3}$ & $\mathbf{0 . 2 6 3}$ & $\mathbf{0 . 8 8 1}$ & $\mathbf{3 . 2 2 4}$ & $\mathbf{0 . 0 0 4}$ & $\mathbf{0 . 3 9 4}$ \\
Circularity, pP cells & -0.001 & -0.124 & 0.904 & 0.001 & 0.001 & 0.002 & 0.201 & 0.844 & 0.003 \\
Leaf rim, TEM & & & & & & & & & \\
Vac size & $\mathbf{5 . 7 8 1}$ & $\mathbf{2 . 5 0 4}$ & $\mathbf{0 . 0 2 7}$ & $\mathbf{0 . 6 2 1}$ & $\mathbf{0 . 6 2 1}$ & $\mathbf{5 . 9 8 5}$ & $\mathbf{2 . 6 1 3}$ & $\mathbf{0 . 0 2 6}$ & $\mathbf{0 . 6 2 9}$ \\
Chl size & 0.234 & 2.161 & 0.062 & 0.514 & 0.514 & $\mathbf{0 . 2 2 8}$ & $\mathbf{2 . 7 8 3}$ & $\mathbf{0 . 0 2 2}$ & $\mathbf{0 . 6 3 1}$ \\
Pl density & 0.557 & 0.469 & 0.659 & 0.033 & 0.033 & -2.249 & -0.217 & 0.840 & 0.008 \\
Pl size & $\mathbf{1 . 9 6 3}$ & $\mathbf{3 . 6 2 4}$ & $\mathbf{0 . 0 0 5}$ & $\mathbf{0 . 7 5 7}$ & $\mathbf{0 . 7 5 7}$ & 1.219 & 1.984 & 0.116 & 0.419 \\
\hline
\end{tabular}

Abbreviations: LM - light microscopy; TEM - transmission electron microscopy; pP - palisade parenchyma; Vac size - percentage area of largest vacuole within $\mathrm{pP}$ cells; Chl size - percentage area of chloroplasts within pP cells; Pl density - plastoglobule frequency per chloroplast; Pl size - percentage area of plastoglobules within chloroplasts.

\section{CAPTIONS}

Fig. 1. Location of and level of salt contamination at the study sites.

Fig. 2. Visible injury by salt stress within foliage and at a street site from Riga's street greenery (Meierovica 1; September 16, 2014). For microscopy assessments, leaf center (light green) and rim (teal blue) disks were excised apart the main center vein and next to salt-triggered necrosis, within still green foliar tissues.

Fig. 3. Principal changes in the concentration of macro- and micronutrients, as a function of $\mathrm{Na}$ and $\mathrm{Cl}$ accumulation within foliage of trees at the study sites. The data points represent site averages $(+\mathrm{SE})$. Statistics refer to linear mixed effects models (LMEM). Solid lines and shaded areas indicate significant $(\mathrm{P}[?] 0.05)$ linear regressions and $95 \%$ confidence intervals.

Fig. 4. Tissue- $(\mathbf{A}-\mathbf{C})$ and cell-level $(\mathbf{H}-\mathbf{K})$ allocation of salt contaminants (Na, $\mathrm{Cl})$ and some macronutrients (K, Ca) within leaf rim samples of Tilia $x$ vulgaris leaves from moderately (B Meierovica 1) and strongly (C, H-K Aspazijas) contaminated versus control site (A NBG) in the street greenery of Riga. D -GElement spectra obtained for the element maps ( $\mathbf{D}$ for $\mathbf{A}, \mathbf{E}$ for $\mathbf{B}, \mathbf{F}$ for $\mathbf{C}, \mathbf{G}$ for $\mathbf{H}-\mathbf{K}$ ). The salt contaminants were found within all leaf blade tissues. At cell level, they primarily accumulated within vacuoles (v) and were missed within cell walls $(\mathrm{cw})$. Other structures: $\mathrm{uE}-$ upper epidermis, $\mathrm{pP}$ - palisade parenchyma, sP - spongy parenchyma, $\mathrm{lE}$ - lower epidermis. The whitish globular structures represent ice contamination. Average foliar concentrations of $\mathrm{Na} / \mathrm{Cl}: 86 \pm 8 / 760 \pm 121 \mathrm{mg} \mathrm{kg}^{-1}(\mathrm{NBG}, \mathbf{A}$ ,D ), 4020 $\pm 739 / 7333 \pm 1746 \mathrm{mg} \mathrm{kg}^{-1}$ (Meierovica 1,B , E ), 9733 $\pm 1964 / 13917 \pm 2022 \mathrm{mg} \mathrm{kg}^{-1}$ (Aspazijas, C , $\mathbf{F}-\mathbf{H}$ ). Technical specifications: High pressure frozen leaf samples planed by cryo-ultramicrotomy and examined using a cryo-FEG-SEM in high-vacuum cryo-mode $\left(-160{ }^{\circ} \mathrm{C}\right)$ at acceleration voltage of $20 \mathrm{kV}$, magnification of 1350x (A-F) and 4500x (G-K), 9 mm working distance, HDBSD detectors for imaging and X-ray Energy Spectrometer for micro-analysis; element spectra and maps obtained by scanning during 1500 s (200 us dwell time); measurements cumulated over 30 frames and mapped at $512 \times 384$ ppi resolution (each point in elementary map representing the total number of counts for the element during mapping); element maps overlaid on HDBSD images; scale of spectra: $71517 \mathrm{cps}$.

Fig. 5. Nutrient content (mass percentages) of vacuolar medium within leaf rim samples of Tilia $x$ vulgaris leaves from salt contaminated sites (average foliar concentrations of $\mathrm{Na} / \mathrm{Cl}$ at Meierovica 1, Gertrudes, Aspazijas: $4020 \pm 739 / 7333 \pm 1746,7067 \pm 677 / 7083 \pm 682,9733 \pm 1964 / 13917 \pm 2022 \mathrm{mg} \mathrm{kg}^{-1}$. The values represent averages per tissue $(+\mathrm{SE}$ ) of measurements performed along two transect through the leaf blade, in one 
leaf sample per site $(\mathrm{N}=3)$. The insert graph shows the vacuolar nutrient content at the asymptomatic NBG site (average foliar concentrations of $\mathrm{Na} / \mathrm{Cl}$ : 86 $88 / 760 \pm 121 \mathrm{mg} \mathrm{kg}^{-1}$ ). Abbreviations: $\mathrm{uE} \mathrm{-} \mathrm{upper} \mathrm{epi-}$ dermis, $\mathrm{pP}$ - palisade parenchyma, $\mathrm{sP}$ - spongy parenchyma, $\mathrm{lE}$ - lower epidermis. Technical specifications: High-pressure-frozen leaf samples planed by cryo-ultramicrotomy and examined using a cryo-FEG-SEM in cryo-mode at acceleration voltage of $10 \mathrm{kV}$ and magnification of 2200x (260 pA of current, $9.5 \mathrm{~mm}$ working distance). Collection of EDS spectra by each measurement point during $30 \mathrm{~s}$. Half-quantitative nutrient mass percent composition (weight \%) of vacuolar sap estimated on the basis of deconvoluted spectrum of each element (XPP deconvolution).

Fig. 6. Structural effects of salt contamination in symptomatic leaves of Tilia $x$ vulgaris from moderately (B, $\mathbf{E}, \mathbf{H}, \mathbf{L})$ and strongly $(\mathbf{C}, \mathbf{F}, \mathbf{I}, \mathbf{J}, \mathbf{M})$ contaminated sites in the street greenery of Riga. Asymptomatic leaves from NBG (A, D, G, K ). Samples from the leaf center $(\mathbf{A}-\mathbf{F})$ and leaf rim region $(\mathbf{G}-\mathbf{M})$. In $\mathrm{pP}$ cells of symptomatic leaves, salt contamination caused an increase in the cell size driven by that of vacuome, with one large vacuole containing many vesicular inclusions (* in H-J ) filling most of cell volume finally (v; E, F, H-J ). The cytoplasm showed degenerative changes (\# in $\mathbf{M}$ ) and an increase of autophagic vesicles (av). The chloroplasts (ch; L, M ) were also degenerated, with larger plastoglobules (pl; E, F,L, M ) protruding and being expelled (\&) into the vacuole. Other structures: $\mathrm{lE}$ : lower epidermis, m: mitochondria, mvb: multivesicular body, n: nucleus, pP: palisade parenchyma, sP: spongy parenchyma, st: starch, ta: tannin body, uE: upper epidermis. Average foliar concentrations of Na/Cl: $86 \pm 8 / 760 \pm 121 \mathrm{mg} \mathrm{kg}^{-1}(\mathbf{A}, \mathbf{D}, \mathbf{G}, \mathbf{K})$, $4020 \pm 739 / 7333 \pm 1746 \mathrm{mg} \mathrm{kg}^{-1}(\mathbf{B}, \mathbf{E}, \mathbf{H}, \mathbf{L}), 9733 \pm 1964 / 13917 \pm 2022 \mathrm{mg} \mathrm{kg}^{-1}(\mathbf{C}, \mathbf{F}, \mathbf{I}, \mathbf{J}, \mathbf{M})$. Technical specifications: A-F : $1.5 \mu \mathrm{m}$ semi-thin cuttings stained with toluidine blue and acid fuchsine and observed in diascopic light microscopy; G-M: $75 \mathrm{~nm}$ ultra-thin sections stained with uranyl acetate and lead citrate, and observed in TEM.

Fig. 7. Structural responses within palisade cells of leaf rim samples, as a function of $\mathrm{Na}$ and $\mathrm{Cl}$ accumulation within foliage of trees at the study sites. The data points represent site averages $(+\mathrm{SE})$. Statistics refer to linear mixed effects models (LMEM). Solid lines and shaded areas indicate significant (P[?]0.05) linear regressions and 95\% confidence intervals. Abbreviations: $\mathrm{pP}$ : palisade parenchyma, $\mathrm{Pl}$ size: percentage area of plastoglobules within chloroplasts. Vacuole size: percentage area of largest vacuole within $\mathrm{pP}$ cells.

Fig. 8. Multivariate structural responses to salt contamination in palisade parenchyma of leaf rim samples - RDA models. Correlation biplot based on a redundancy analysis of the structural data measured in mesophyll, showing the relationship between markers of salt injury (response variables, black arrows) and salt concentration in foliage ( $\mathrm{Na}, \mathrm{Cl}$ explanatory variables; blue arrows). The leaf injury (i.e. percentage area of leaf showing necrosis, light blue arrow) was passively projected, as a supplementary variable. Altogether, the first and second canonical axis explained $78.12 \%$ of total variance in the mesophyll structure dataset, whilst only the first axis was significant $(P<0.001)$. The color of each tree score shows the average Nacontamination within lime tree foliage at the five sampling sites ( $86+7 \mathrm{mg} \mathrm{kg}-1,895+477 \mathrm{mg} \mathrm{kg}^{-1}, 4507$ $+534 \mathrm{mg} \mathrm{kg}^{-1}, 8000+793 \mathrm{mg} \mathrm{kg}-1$; $=3$ trees per site), with each site centroid indicated by a cross and label. Abbreviations for the descriptor variables: ChS chloroplast size, CS cell size, circ Cell circularity, PID plastoglobule density, PIS plastoglobule size, VS vacuome size.

Fig. S1. Element mapping by means of compact FIB-Tof-SIMS performed during the microlocalisation trials, with a focus on $\mathrm{Na}$ and $\mathrm{Cl}$ ions within cross-sections of leaf rim samples collected in the street greenery of Riga. The $\mathrm{Na}$ and $\mathrm{Cl}$ concentration of leaf sample is indicated directly in the Fig. A, B Microlocalisation trial applying a freeze-substitution protocol. The $\mathrm{Na}$ and $\mathrm{Cl}$ contaminants have been dislodged from the vacuole to cytosol and cell wall compartments during the freeze-substitution. C, D Microlocalisation trial using the cryo-fixed sample block, after trimming by cryo-ultramicrotomy and controlled freeze-drying (as a consequence of of intercellular spaces, large vacuoles and lignified structures, the sections fell apart and could not be retrieved). Dislodging of salt contaminants was reduced but the tissue and cell structure was too much distorted for enabling the observation of salt distribution among the storage compartments. Sampling sites: Barona $(\mathbf{A}, \mathbf{B})$; Meierovica $1(\mathbf{C}, \mathbf{D})$.

Technical specifications: Sample preparation: A, Bfreeze substitution of samples in LN2 using an EM AFS2 
(Leica Microsystems) at $\mathrm{ZMB}\left(1 \% \mathrm{OsO}_{4}\right.$ in $100 \%$ acetone $-90^{\circ} \mathrm{C} 8$ hours, graded temperature increase to $0^{\circ} \mathrm{C}$ in 16 hours, rinsing in $100 \%$ acetone, infiltration by a series of graded acetone/Epon-Araldite mixture at $+4^{\circ} \mathrm{C}$ and embedding in Epon-Araldite). Thin cuttings $(100 \mathrm{~nm})$ sectioned using a Reichert UltraCut $\mathrm{S}$ ultramicrotome, mounted on custom-made Si-wafers and coated with 4-6 nm Au. C, D stepwise freezedrying of $400 \mu \mathrm{m}$-deep trimmed block sample $(6.2 \mathrm{~h}$ in total, using a modified Bal-Tec BAF 060), prior to mounting on Al-stub. Element mapping: Visualization and mapping of $23 \mathrm{Na}^{+}$and $35 \mathrm{Cl}^{-}$ions by means of Focused Ion Beam-Secondary Ion Mass Spectrometer microscope (compact FIB-SIMS) at the Swiss Research Institute for Applied Materials Sciences and Technology (EMPA) in Thun, Switzerland (Ga ion beam, 20 $\mathrm{keV}, 180 \mathrm{pA}, 100 \mathrm{x} 100 \mu \mathrm{m}$ view field). 20keV 180-200 pA, 100x100 $\mu \mathrm{m}$.

Fig. S2. Structural effects of salt contamination in the upper epidermis cells of Tilia $x$ vulgaris foliage from moderately $(\mathbf{B}, \mathbf{E})$ and strongly $(\mathbf{C}, \mathbf{F}, \mathbf{G})$ contaminated sites in the street greenery of Riga (leaf rim samples). A, BAsymptomatic material from the National Botanical Garden. Within epidermis cells, salt accumulation further hastened the ontological senescence by exacerbating the ongoing degenerative changes, such as the increase in size of plastoglobules (pl) within leucoplasts $(\mathrm{l} ; \mathbf{B}, \mathbf{E}, \mathbf{F}, \mathbf{G})$, condensation of chromatin within nucleus $\left({ }^{*} \mathrm{n} ; \mathbf{B}, \mathbf{E}\right)$, or higher frequency of autophagic vesicles (av) and multivesicular bodies (mvb; B, E ). Other structures: \#, fibrillous mucilage material, m: mitochondria v: vacuole. Average foliar concentrations of $\mathrm{Na} / \mathrm{Cl}: 86 \pm 8 / 760 \pm 121 \mathrm{mg} \mathrm{kg}^{-1}(\mathbf{A}, \mathbf{D}), 4020 \pm 739 / 7333 \pm 1746 \mathrm{mg} \mathrm{kg}^{-1}(\mathbf{B}, \mathbf{E})$, $9733 \pm 1964 / 13917 \pm 2022 \mathrm{mg} \mathrm{kg}^{-1}(\mathbf{C}, \mathbf{F}, \mathbf{G})$. Technical specifications: $75 \mathrm{~nm}$ ultra-thin sections stained with uranyl acetate and lead citrate, and observed with TEM.
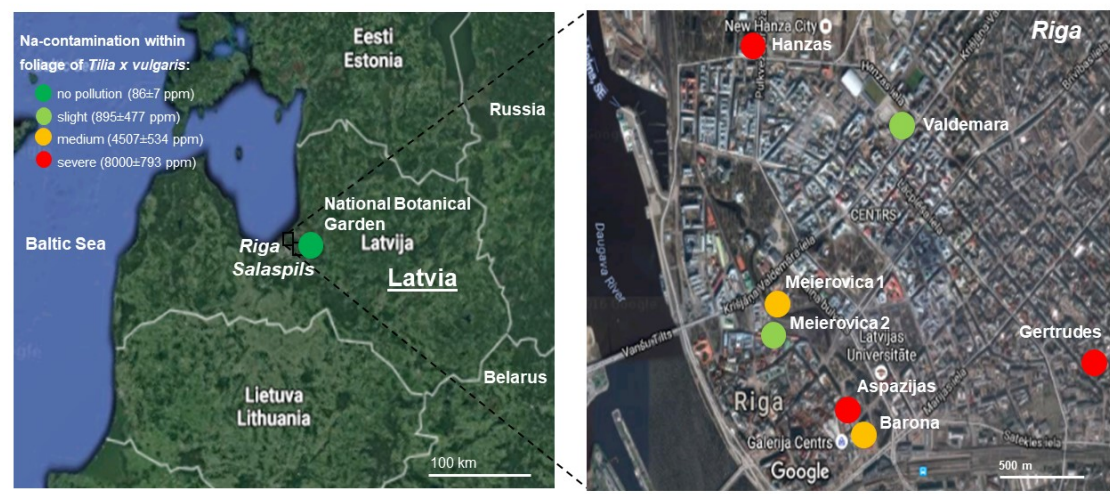


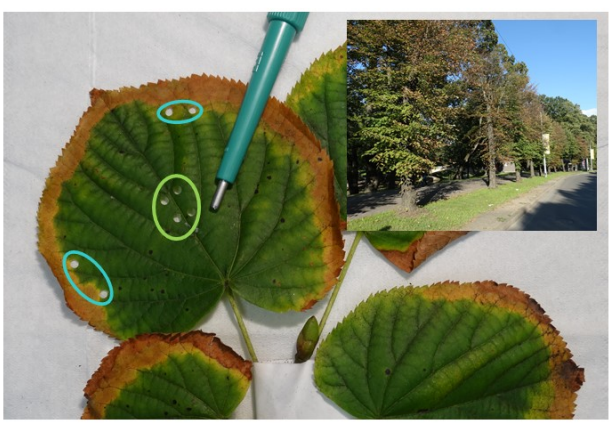



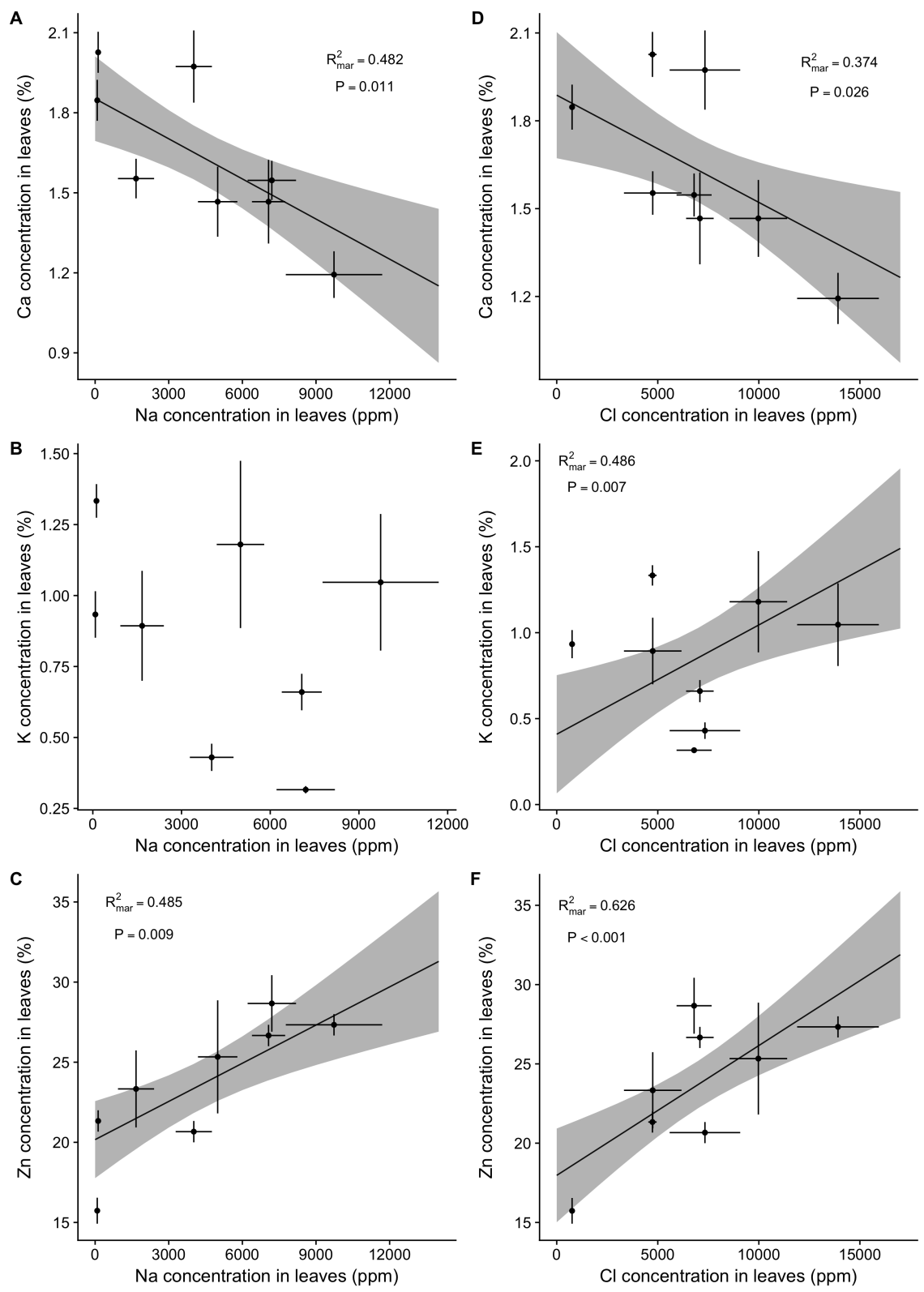

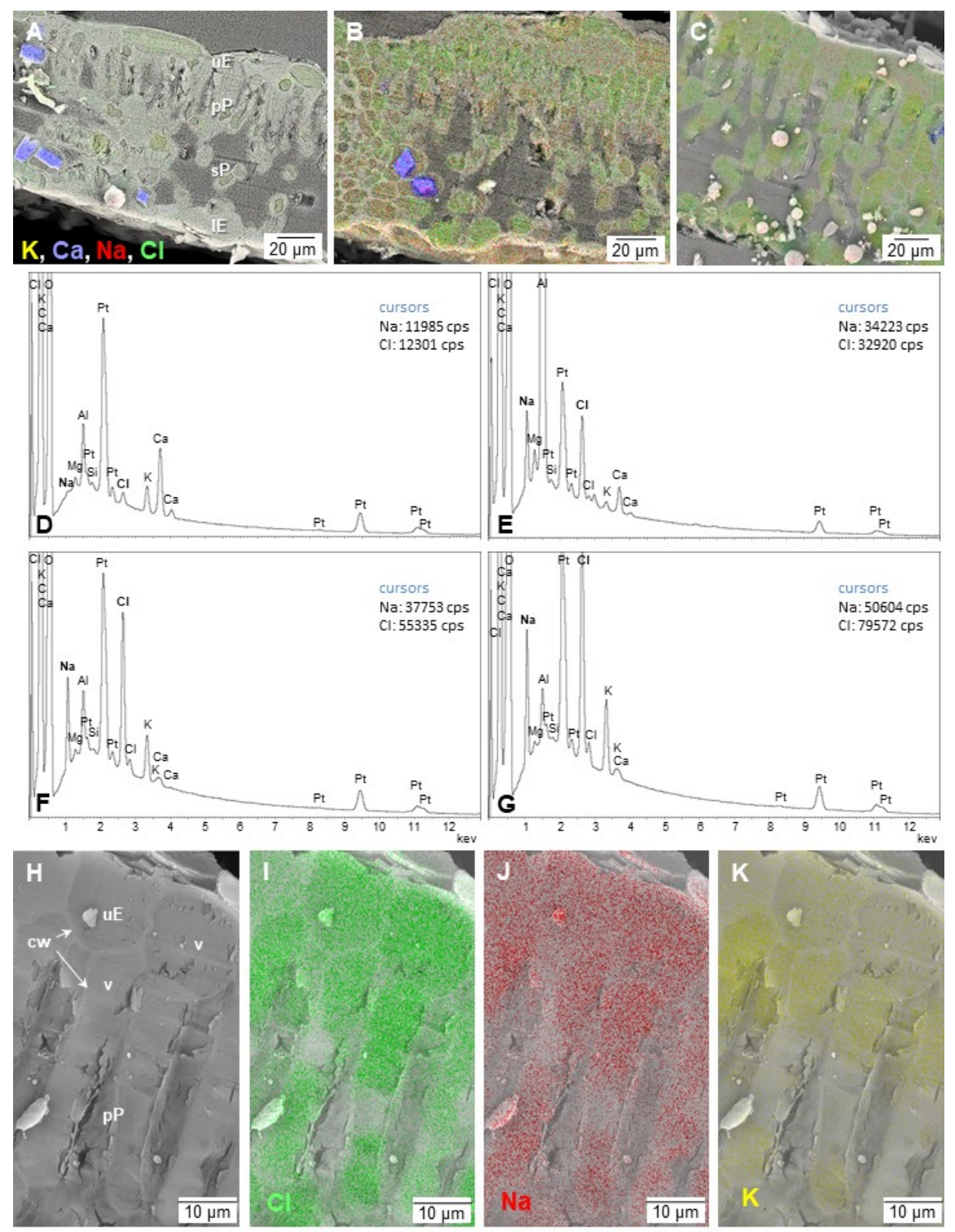

\section{Hosted file}

Fig5_fn.docx available at https://authorea.com/users/298882/articles/428235-saltaccumulation-and-effects-within-foliage-of-tilia-x-vulgaris-trees-from-the-streetgreenery-of-riga-latvia 

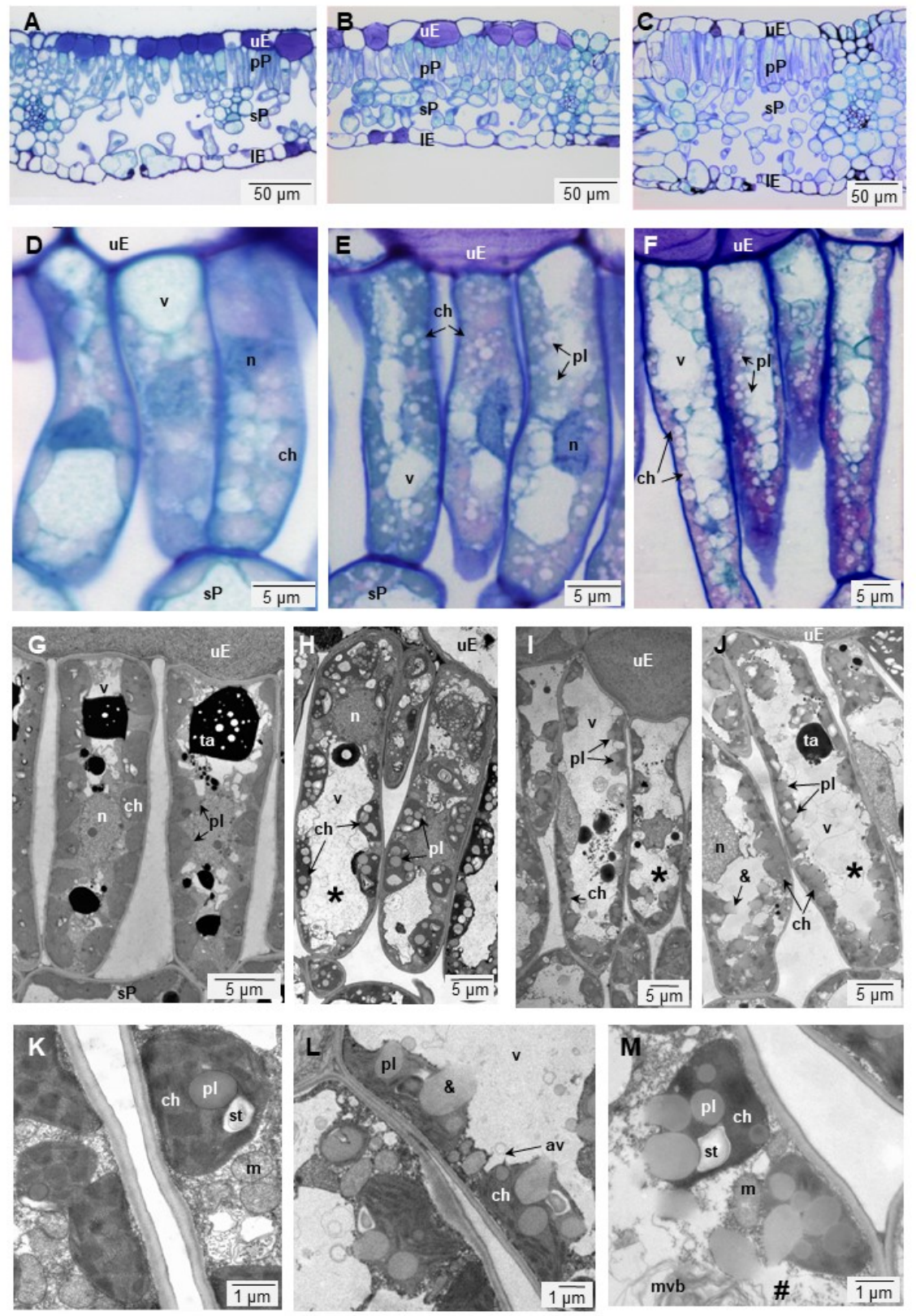

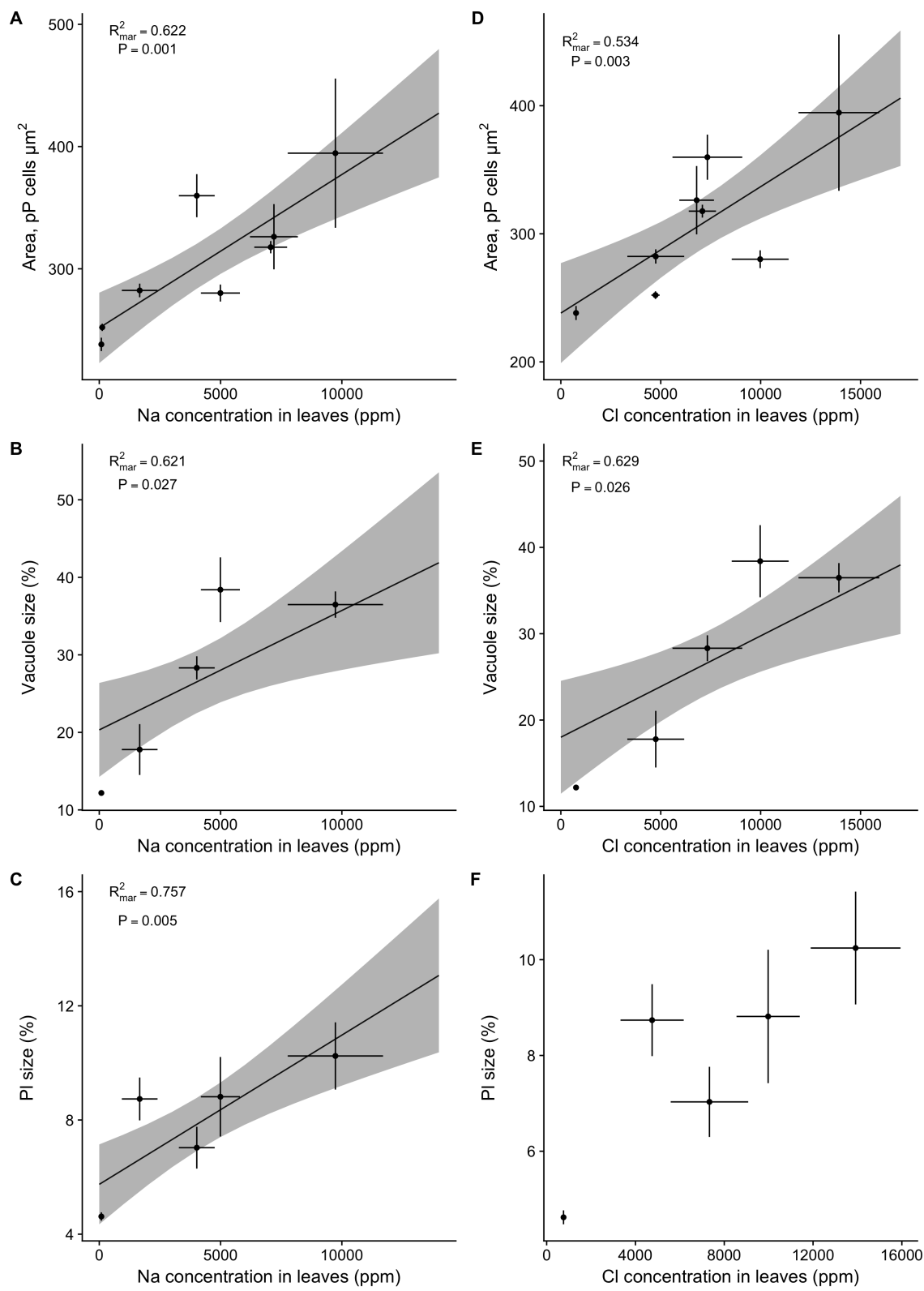

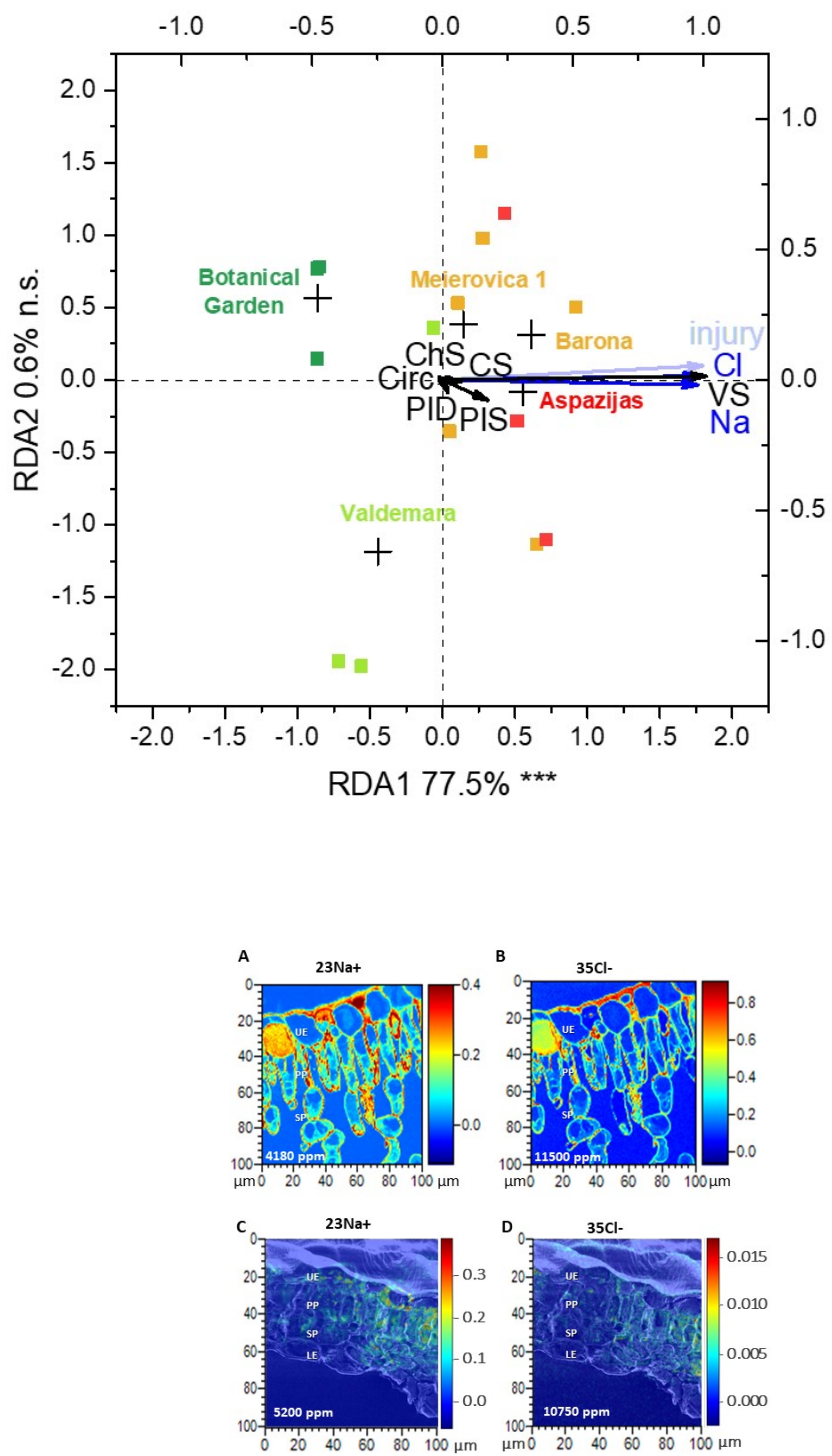

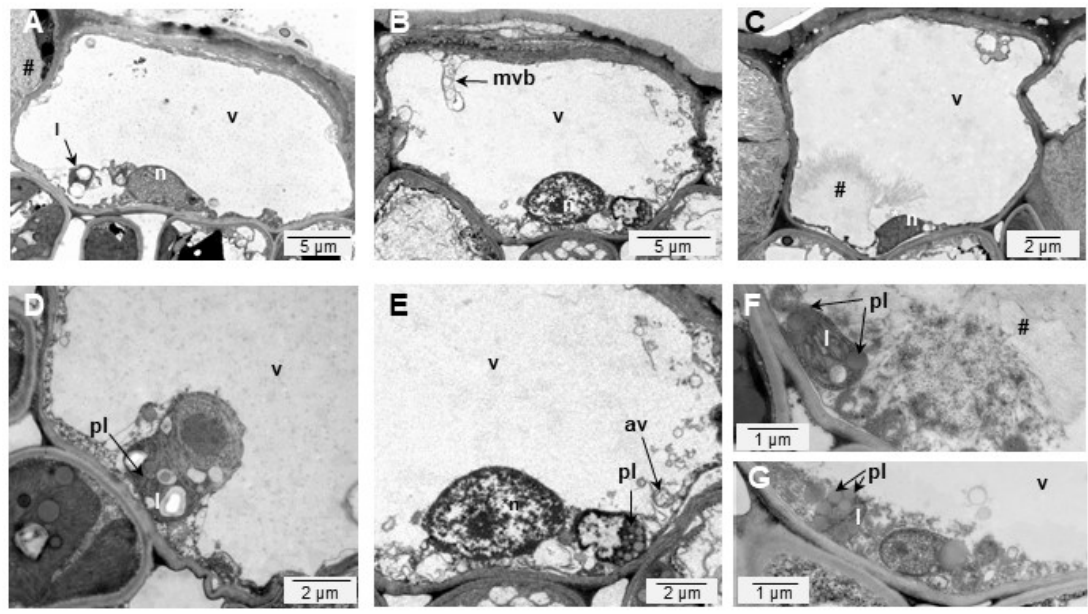